\title{
Oil Press-Cakes and Meals Valorization through Circular Economy Approaches: A Review
}

\author{
Petraru Ancuta and Amariei Sonia * \\ Faculty of Food Engineering, Ștefan cel Mare University of Suceava, 720229 Suceava, Romania; \\ ancuta.petraru@fia.usv.ro \\ * Correspondence: sonia@usm.ro; Tel.: +40-740-311-291
}

Received: 23 September 2020; Accepted: 20 October 2020; Published: 22 October 2020

check for updates

\begin{abstract}
The food industry generates a large amount of waste every year, which opens up a research field aimed at minimizing and efficiently managing this issue to support the concept of zero waste. From the extraction process of oilseeds results oil cakes. These residues are a source of bioactive compounds (protein, dietary fiber, antioxidants) with beneficial properties for health, that can be used in foods, cosmetics, textile, and pharmaceutical industries. They can also serve as substrates for the production of enzymes, antibiotics, biosurfactants, and mushrooms. Other applications are in animal feedstuff and for composites, bio-fuel, and films production. This review discusses the importance of oilseed and possible valorization methods for the residues obtained in the oil industry.
\end{abstract}

Keywords: residues; sustainability; oil cake; bioactive compounds; edible films

\section{Introduction}

In recent decades, due to the current planet issues (e.g., over-exploitation and mismanagement of resources, the unsustainable consumption behaviors from consumers, the degradation of the environment and equilibrium of the ecosystems, climate change), it is necessary to transition to a circular economy model based on the development of new strategies for making the best use of our resources and for the elimination of the concept of wastes along the supply chain. In this model, materials are recycled (a process in which wastes are transformed into value-added products by making them input elements for other products) and re-circulated during processing to create the concept "waste $=$ food" [1-3].

Any substance or object already disposed or intended to be discarded by holders is called waste. Food wastes are edible materials (lost, discarded, or consumed by pest) collected from the food industry in all phases, from primary agriculture up to production, processing, and direct consumption in the households. The Food Agriculture Organization declared that annually one third of the total food production became lost, about 1,3 billion tons (20\% in oilseeds, meat and dairies, $30 \%$ in cereals, $35 \%$ in fish and, $40-50 \%$ in fruit and vegetables). During the supply chain, a quantity of $54 \%$ of the total waste results from cultivation and post-harvest and $46 \%$ from processing, distribution, and utilization. Administration of these residues/wastes/by-products could be problematic due to the high disposal costs in landfills and the creation of serious environment problems [4,5]. A solution for reducing food wastes is extracting the maximum value from wastes and by-products. The last ones contain high amounts of bioactive compounds (carbohydrates, lipids, organic acids, proteins, vitamins, minerals, and antioxidants) with numerous health benefits (anti-tumoral, viral, bacterial, and mutagenic abilities) that can be isolated and employed in foods, pharmaceutics, cosmetics, and textiles. Achieving this can be a challenge, but at the same time could add more value to food, reducing disposal costs and risks caused by residues [6]. Other alternatives, after the extraction are: conversion in energy, introduction 
in human food, livestock and fish feedstuff, production of fertilizers and compost (generated from the aerobic decomposition of organic matter by microorganisms and insects) [1].

This paper provides a critical review ofthe existing literature about the possible ways to re-utilized the by-products obtained from the oil industry.

\section{Oilseed, General Aspects}

Oilseeds are seeds used in most countries as a source of vegetable oils. Soybean and walnut are cultivated in USA, Brazil and Argentina [7,8]. The largest rapeseed producers are the European countries (Germany, France), Russia, Pakistan, Canada, Australia, China, and India $[9,10]$. The world leading producers of sunflower seeds are Russia, Ukraine, Argentina, USA, China, India, and Turkey [10]. Sesame is grown primarily in Asia, Africa, India, China, and South America [11]. Pumpkin is largely cultivated in America, Europe (such as Austria, Slovenia, Croatia, Hungary, Greece, Bulgaria, Romania, and Turkey), Africa, and Asia [12-14]. In India, China, United States, and Ethiopia linseed is mainly cultivated flaxseed [15].

Sunflower, rapeseed, coconut, mustard, soybean, cotton, corn, oat, peanut, olive, and palm are oil-producing crops. Oil can be extracted also from nuts as almond, hazelnut, walnut, and pumpkin. Depending on the level of production oilseeds are classified as major (soybean, rapeseed, sunflower, sesame, niger, castor) and minor (coconut, palm seed). Globally the most produced oilseed is soybean, followed by rapeseed/canola, sunflower, cottonseed, groundnut, coconut, safflower, and flaxseed. Oilseeds cultivated mainly for oil extraction are rapeseed and sunflower, for proteins is soybean and for fibers is cotton. Linseed can be used for edible and industrial oil production but peanuts non solely for the oil but also for direct consumption [16]. The chemical composition and thus the nutritive values of oilseeds depend on the following factors: oilseed genotype, soil type, climatic condition, growing area, agricultural practices, and processing conditions [8]. They are rich in phytochemicals (phenolic compounds, carotenoids, polyphenols, flavonoids, lignans, phytosterols, tocopherols, and tocotrienols), protein, fat, ash, fiber, carbohydrate, vitamins (A, K, E, C, B $B_{1}, B_{2}, B_{3}, B_{6}$ ), and minerals ( $\mathrm{P}, \mathrm{Cu}, \mathrm{Ca}, \mathrm{K}, \mathrm{Mg}, \mathrm{Mn}, \mathrm{Fe}, \mathrm{Zn}, \mathrm{Se}$ ). The vitamins are important for the functioning of the skin, nerves, and digestive system, maintenance of cells and have an antioxidant role, the minerals are involved in the metabolic and enzymatic processes and the phytochemical possess antioxidant activity, reduces tumors, inflammations, and improve immunity. For these reasons, oilseeds have an important role in human nutrition [17].

\section{Oilseed Production Process and by-Products Physiochemical Properties}

Oilseeds are cleaned, dehulled, grinded, cooked (destruction of microorganism and oil cell, enzymes inactivation, coagulation of proteins), and then are subjected to oil extraction. Each phase of the process generates waste with residual bioactive compounds that can be recovered: steams, leaves, pods, and broken grain in the cleaning steps and in the dehulling phase, hulls $[16,18]$.

The two traditional methods to extract oil involve either the use of a mechanical press (hot and cold pressing) or a solvent. When the process is mechanical the oilseeds are heated (100 degrees) and the oil is extracted with a screw-press. Alternately, in cold pressing, the temperature of heating is kept at 50-60 degrees. The use of a solvent helps to maximize the oil recovery. The differences in chemical compositions between the cold-pressed and expeller cakes were in crude protein, fat, and crude fiber content. The protein content of the cold-extracted cakes was lower in comparison to that extracted at high temperatures. Regarding the fat content, the mechanical expeller cakes have $6-7 \%$ and the solvent extracted ones have $<1 \%$. The product resulting directly from the expeller is called a cake, and when it has undergone an additional solvent de-oiling process the term meal is used. This conventional oil extraction method can be replaced by modern/green techniques (pressurized liquid, pulsed electric field, high hydrostatic pressure, and high voltage electrical discharges) because they are more rapid and less solvent consuming [19-23]. 
After the extraction of oil from seeds, the principal by-product obtained is oil cake/meal. Oilcakes/meals are classified into two categories_edible and non-edible. Edible oil cake (soybean, groundnut, rapeseed, sunflower, coconut, cottonseed, safflower, flaxseed) have a high nutritional value and can be used in animal and human consumption as processed ingredients (protein concentrate, isolate, hydrolysate), a substrate (in the production of bioactive compounds, surfactants, enzymes, antibiotics, vitamins, pigments, flavors, and amino acids) and source of antioxidants. The defatted edible cakes can be used in the diet of undernourished people by incorporating them in bakery, infant products, and multipurpose supplements. Non-edible oilseed cake/meal (castor, neem, mauha, karanja and linseed) are used as manure due to the presence of toxic compounds [22].

According to the U.S. Department of Agriculture (USDA), the world production of oilseeds in 2018/2019 was 600.47 million metric tons, hence a large amount of press cakes and residues are available. The use of these by-products and residues from the oil industries is a sustainable alternative to reduce waste disposal and also contributes to the development at low cost, of new products rich in nutrients [17].

Oilcakes/meals composition depends on variety, extraction method, and growing condition. Taste and smell are characteristics to the initial raw materials without musty, mold, pro-rancid, and foreign smells. Walnut oilcakes are yellow to light brown, and sweetish. The color of pumpkin seeds oilcake is brown to brownish green with an insipid and a sweetish flavor. Sesame oilcake color varies from cream to light brown and has sweetish, insipid taste. Oilcake from flaxseeds have different shades of brown with a neutral and insipid taste [24].

As shown in Table 1, the highest content in proteins was found in groundnut cake then soybean, almond, chia, rapeseed, sunflower, cottonseed, pumpkin, hemp, safflower, sesame, coconut, flaxseed, and olive oilcakes. The oil content in sunflower and rapeseed is over $40 \%, 15-25 \%$ in soybean and cotton, another major source is peanut (56\%) [18].

Despite the fact that oilcakes are low-processed materials they are safe. Improper storage and handling can cause rancidity (unpleasant taste and smell). During four months of storage, Tarek-Tilistyak et al. [25] observed that the water activity remains stable inhibiting bacterial and mold growth. The macronutrients decrease after one month and the lowest level of contamination was detected in walnut and the highest in linseed. Further, study investigated the influence of different packaging. More precisely, if flaxseed oilcake is packed either in paper or polypropylene and stored for six months at room temperature it can maintain the healthy properties, nutrients, and nutraceuticals contents typical of the raw material. Cakes stored either in paper or plastic show similar behavior-a modest decrease of antioxidant activity, optimal omega-6/omega-3 ratio, increase in $\alpha$-tocopherol (possible from the conversion of the $\gamma$-form), decrease in crude fat ( $48 \%$ in paper and $51 \%$ in plastic) and proteins (12\% and $6 \%$ respectively). It was concluded that this method of preservation was efficient and it is preferable the use of paper because is more eco-friendly [26]. It was demonstrated that peanut oilcake, stored twelve months in vacuum packaging with low permeability, regardless of the temperature retained its quality (good water/oil absorption and high content of unsaturated fatty acids), antioxidant capacity, and low microorganism yeast (due to the oxygen restriction that delays their growth and lipid oxidation) [27]. 
Table 1. Chemical composition of oilcake/meals obtained from different methods of extraction.

\begin{tabular}{|c|c|c|c|c|c|c|c|c|}
\hline Type & Moisture \% & Dry Matter \% & Crude Protein \% & Crude Lipid \% & Ash \% & Crude Fiber \% & Carbohydrates \% & Reference \\
\hline \multicolumn{9}{|c|}{ RAPESEED } \\
\hline $\mathrm{SEC}^{1}$ & $3.96-10.59$ & $88-96.04$ & $16-45$ & $1.1-10$ & $6.1-15.8$ & $8.2-17.5$ & $21.38-47.72$ & {$[11,28-36]$} \\
\hline $\mathrm{CPC}^{2}$ & $6-10.8$ & $86.3-94.3$ & $14.03-40.1$ & $5.14-23.1$ & $5-19.7$ & $5.5-15.46$ & $25.1-48$ & {$[17,20,24,32,34,37-47]$} \\
\hline $\mathrm{HPC}^{3}$ & $4.7-10.1$ & $89.9-95.3$ & $36.1-39.1$ & $9.2-12.2$ & $6.9-7.1$ & 13.1 & 31.5 & {$[20,48]$} \\
\hline $\mathrm{M}^{4}$ & $5.8-12$ & 88-94.5 & $33.9-40.6$ & $1.7-23$ & $7-13.9$ & $11-14$ & $35.5-44$ & {$[17,40-42,49]$} \\
\hline \multicolumn{9}{|c|}{ CANOLA } \\
\hline SEC & $7.3-12.09$ & $87.91-92.7$ & $34.5-40$ & $2.46-19.34$ & $4.19-6.34$ & $12.05-20.11$ & $8.35-17$ & {$[50,51]$} \\
\hline $\mathrm{CPC}$ & $9.07-10$ & $90-90.93$ & $33.9-37.75$ & 17.96 & $4.50-6.2$ & $9.7-11.63$ & 19.08 & {$[52,53]$} \\
\hline M & 2.86 & 97.14 & 55.47 & 3.08 & 5.56 & 12.05 & 20.98 & [53] \\
\hline \multicolumn{9}{|c|}{ CHIA } \\
\hline SEC & 10.47 & 89.53 & 41.36 & 0.21 & 7.24 & 27.57 & 23.62 & [54] \\
\hline $\mathrm{CPC}$ & $6.8-10.84$ & $89.16-93.2$ & $28.2-35$ & $6.52-11.39$ & $4.58-6.27$ & $23.81-30.46$ & $23.53-30.24$ & {$[54,55]$} \\
\hline \multicolumn{9}{|c|}{ SESAME } \\
\hline SEC & $4-10$ & $90-96$ & $22.65-48.5$ & $1.07-29.94$ & $5.27-13$ & $4-10.36$ & $25.5-34$ & {$[21,28,56-60]$} \\
\hline $\mathrm{CPC}$ & $1.17-16.8$ & $83.2-98.83$ & $16.96-45.9$ & $5.10-48$ & $3.80-12.4$ & $3.28-22,7$ & $22.5-46.96$ & {$[24,58,60-70]$} \\
\hline $\mathrm{HPC}$ & $5.05-9.3$ & 90.7-94.95 & $39.1-47.1$ & $3-13.31$ & $3.41-10.35$ & $3.48-9.97$ & $20.08-42.85$ & {$[58,71]$} \\
\hline $\mathrm{M}$ & $0.25-10.38$ & $89.62-99.75$ & $30.3-59$ & $0.40-5$ & $6.9-11.87$ & $3-29.37$ & $39.9-55.4$ & {$[12,72-75]$} \\
\hline \multicolumn{9}{|c|}{ COCONUT } \\
\hline SEC & $5.75-9.9$ & $90.10-94.25$ & $17.8-19.95$ & $3.22-9.4$ & 2.024 .9 & 10.3 & 47.7 & {$[21,76]$} \\
\hline $\mathrm{CPC}$ & $6.52-11.2$ & $88.8-93.48$ & $17.40-25.2$ & $15.02-15.3$ & $4.13-8.34$ & 10.8 & 53.94 & {$[52,77-79]$} \\
\hline \multicolumn{9}{|c|}{ OLIVE } \\
\hline SEC & N.a ${ }^{5}$ & N.a & $0.3-10.6$ & 4 & $3.4-9.1$ & N.a & N.a & [80] \\
\hline $\mathrm{CPC}$ & 14.8 & 85.2 & $0.4-4.77$ & $8.72-11.1$ & $4.1-6.6$ & $40-60.1$ & $10.1-20.6$ & [80-82] \\
\hline \multicolumn{9}{|c|}{ WALNUT } \\
\hline SEC & 10.59 & 89.41 & $13-38.87$ & $2,45-10$ & 7.48 & $5-33$ & 12.65 & {$[24,25,55,83-88]$} \\
\hline $\mathrm{CPC}$ & $3.6-10 ., 5$ & $91.8-96.4$ & $10.30-50.4$ & $7.95-36.80$ & $2.79-10$ & $6.79-18.5$ & $17.4-49.75$ & {$[84,89]$} \\
\hline \multicolumn{9}{|c|}{ ALMOND } \\
\hline $\mathrm{CPC}$ & 5.80 & 94.2 & 51.3 & 19 & 5.30 & 5.6 & 18.80 & [55] \\
\hline
\end{tabular}


Table 1. Cont.

\begin{tabular}{|c|c|c|c|c|c|c|c|c|}
\hline Type & Moisture \% & Dry Matter \% & Crude Protein \% & Crude Lipid \% & Ash \% & Crude Fiber \% & Carbohydrates \% & Reference \\
\hline \multicolumn{9}{|c|}{ SAFFLOWER } \\
\hline $\mathrm{CPC}$ & 6.8 & 93.2 & 23.25 & 9.14 & 5.10 & 34.41 & 55.71 & [55] \\
\hline \multicolumn{9}{|c|}{ SOYBEAN } \\
\hline SEC & 88.7 & 11.3 & $46-52.4$ & $0.55-8$ & $2-6.96$ & $4.4-75.44$ & $42.8-47.05$ & {$[59,90,91]$} \\
\hline $\mathrm{CPC}$ & $8.4-9.66$ & $90.34-91.6$ & $43.3-45.5$ & $9.3-15.55$ & $5.71-5.91$ & $4.95-11.28$ & $14.98-21.76$ & {$[44,92,93]$} \\
\hline HPC & 89.9 & 10.1 & 39.1 & 9.2 & 6.9 & N.a. & N.a & [48] \\
\hline $\mathrm{M}$ & 12 & $88-95.79$ & $44-49$ & $0.5-0.65$ & $4.21-7.5$ & $3.5-7$ & $35.85-47.79$ & {$[70,94]$} \\
\hline \multicolumn{9}{|c|}{ GROUNDNUT } \\
\hline $\mathrm{CPC}$ & $8.22-4.57$ & $91.78-95.43$ & $41.73-60$ & $7-22.59$ & $1.5-5.76$ & $4.33-8.55$ & $14.1-36.6$ & {$[55,67,95,96]$} \\
\hline \multicolumn{9}{|c|}{ SUNFLOWER } \\
\hline SEC & $2.56-10$ & $90-97.44$ & $31.9-43.38$ & $1-23.6$ & $6.4-7.83$ & $13.07-28.85$ & 25.99 & {$[25,90,97,98]$} \\
\hline $\mathrm{CPC}$ & $2.5-11$ & 89-97.5 & $19.93-44.9$ & $7-16.6$ & $4.69-8$ & $17.4-33.4$ & $15-28.2$ & {$[44,77,95,96,99-101]$} \\
\hline \multicolumn{9}{|c|}{ FLAXSEED } \\
\hline $\mathrm{CPC}$ & $6.89-9.27$ & $90.73-93.1$ & $14.4-41.97$ & $6.11-21.4$ & $4.7-6.27$ & $6.29-12.9$ & $16.26-52.45$ & $\begin{array}{c}{[24-26,44,47,52,68,76} \\
102-105]\end{array}$ \\
\hline HPC & $2.65-6.14$ & $93.86-97.35$ & $28.13-59.62$ & $1.85-2.10$ & $5.26-9.40$ & $9.35-34.77$ & $21.27-25.6$ & {$[53,105]$} \\
\hline $\mathrm{M}$ & $5.75-9.37$ & $90.63-94.25$ & $19.95-34.13$ & $1.87-3.22$ & $2.02-5.72$ & 9.38 & 48.9 & [103] \\
\hline \multicolumn{9}{|c|}{ PUMPKIN } \\
\hline $\mathrm{CPC}$ & $5-8.2$ & $91.8-96.5$ & $29.39-53.98$ & $5.92-36.22$ & $4.20-8.7$ & $3.89-7.1$ & $15.88-19.73$ & {$[24,47,55,77,92,106]$} \\
\hline $\mathrm{M}$ & 8.01 & 91.99 & 60.94 & 0.94 & 9.93 & N.a. & 28.19 & [107] \\
\hline \multicolumn{9}{|c|}{ HEMP } \\
\hline $\mathrm{CPC}$ & $6.35-13.61$ & $86.39-93.65$ & $23.25-33.45$ & $0.51-14.02$ & $3.30-9.78$ & $17.41-60.38$ & $2.80-48.54$ & {$[47,53,55,99,106,108]$} \\
\hline HPC & 2.15 & 97.85 & 52.48 & 1.54 & 6.52 & 18 & 19.31 & {$[52]$} \\
\hline $\mathrm{M}$ & 9.37 & 90.63 & 32.07 & 0.97 & 9.65 & N.a. & 57.31 & [107] \\
\hline \multicolumn{9}{|c|}{ COTTONSEED } \\
\hline $\mathrm{CPC}$ & N.a & N.a & 24.79 & 8.91 & 6.2 & 7 & 32.2 & [96] \\
\hline
\end{tabular}

${ }^{1}$ SEC-solvent extracted cake; ${ }^{2}$ CPC- cold-pressed cake; ${ }^{3}$ HPC- expeller cake, ${ }^{4}$ M-meal; ${ }^{5}$ N.a- not analyzed 


\section{Anti-Nutritional Factors}

Anti-nutritional factors are substates of natural or synthetic origin, found in the human diet or animal feed, which can affect the health, and growth performance of livestock. These factors can have different effects on animals depending on their digestive process, for example, trypsin inhibitors have a negative effect on monogastric animals, but not in ruminants because it is degraded [109]. The direct utilization of oilseed cakes in human or animal nutrition is limited by the presence of antinutrients, which influences the organoleptic properties, protein digestibility, and macro-/micro-elements bioavailability [22]. The major antinutrient in oil cakes are presented in Table 2.

Canola meal contains phenolics, phytic acid, and glucosinolates, that can cause problems in food. The main antinutritional factor (30 times higher compared to soybean) are the phenolics acid esters, especially sinapine. This binds to protein and creates a complex that confers dark color, bitter taste, and through oxidation, poor digestibility. Regarding glucosinolates, it was demonstrated to have a positive effect on health in low proportion [110]. When seeds are crushed, enzymes such as myrosinase are liberated, which are responsible for the hydrolyzation of glucosinolates in glucose and various toxic chemicals (isothiocyanate or thiocyanate ions) [10].

Cyanogenic glycosides are the major antinutrient in flaxseed cake. In the gastrointestinal tract, during digestion they form hydrogen cyanide, causing below $50 \mathrm{mg} / \mathrm{Kg}$ acute toxicity in adults. Linatine, another antinutritional factor can cause pyridoxine $\left(\mathrm{B}_{6}\right)$ deficiency [111].

The majority of oilcakes (rapeseed/canola, sesame, sunflower, soybean, groundnut, hempseed) contain antinutrients such as phytic acid and trypsin inhibitors, which can diminish protein and vitamin utilization. More precisely the second one (trypsin inhibitors) connects to the digestive enzyme trypsin, thus reducing proteins adsorption and digestion. [112].

Saponins are a group of steroidal glycosides (natural foam producers) that cause hemolysis and interference in bile acids, lipid-soluble vitamins, cholesterol, and dietary lipids [111].

Phytic acid can bind with minerals, proteins and amino acids forming phytates and insoluble complexes, thus reducing essential nutrient bioavailability, and digestibility. They can also lower the minerals availability and amylase activity [67].

Table 2. Main antinutritional factors.

\begin{tabular}{|c|c|c|c|}
\hline Types & Oilcakes & Effect & Reference \\
\hline Sinapine & Rapeseed/Canola & $\begin{array}{c}\text { dark color; undesirable taste, } \\
\text { indigestibility; lower nutritional value }\end{array}$ & {$[51,94,110]$} \\
\hline Phytic acid & $\begin{array}{l}\text { Rapeseed/Canola, } \\
\text { Sesame, Sunflower, } \\
\text { Soybean, Groundnut, } \\
\text { Hempseed }\end{array}$ & $\begin{array}{l}\text { decrease mineral availability and } \\
\text { absorption and digestion of proteins } \\
\text { and starch }\end{array}$ & {$[90,94,113]$} \\
\hline Tannis & $\begin{array}{l}\text { Soybean, Sesame, } \\
\text { Sunflower, Groundnut, } \\
\text { Rapeseed, Hempseed }\end{array}$ & $\begin{array}{l}\text { astringency, inhibit protein } \\
\text { adsorption, produce amino } \\
\text { acid imbalance }\end{array}$ & {$[90,94,113]$} \\
\hline Saponins & $\begin{array}{l}\text { Soybean, Sunflower, } \\
\text { Hempseed }\end{array}$ & $\begin{array}{c}\text { hemolysis, interference in bile acids, } \\
\text { lipid-soluble vitamins, cholesterol and } \\
\text { dietary lipids }\end{array}$ & {$[90,94]$} \\
\hline Glucosinolates & $\begin{array}{l}\text { Rapeseed/Canola, } \\
\text { Hempseed }\end{array}$ & $\begin{array}{l}\text { reduce feed intake, impaired thyroid } \\
\text { function, liver enlargement }\end{array}$ & {$[10,94,113]$} \\
\hline Cyanogenic glycosides & Hempseed, Flaxseed & $\begin{array}{l}\text { pyridoxine }\left(\mathrm{B}_{6}\right) \text { deficiency } \\
\text { protein indigestibility and alter their }\end{array}$ & {$[94,111,114]$} \\
\hline Chlorogenic acid & Sunflower & $\begin{array}{l}\text { organoleptic properties, storage life } \\
\text { and stability in food systems }\end{array}$ & {$[94,101]$} \\
\hline Trypsin inhibitors & $\begin{array}{l}\text { Soybean, Sunflower, } \\
\text { Sesame, Groundnut, } \\
\text { Hempseed, Flaxseed }\end{array}$ & reduce protein digestibility & {$[90,94,112,113]$} \\
\hline
\end{tabular}

The elimination or inactivation of these toxic substances can be achieved by various methods: physical (dehulling, heat-cooking, autoclaving, toasting), chemical (ammoniation, the addition of choline, methionine, ferrous sulphate, sodium carbonate), enzymatic and fermentative. 
Heat treatment can remove or reduce effectively cyanogenic glycosides, proteases, trypsin inhibitors, glucosinolates, and phytic acid (the last one was reduced by $43 \%$ ). The extraction of protein isolates is another method useful to eliminating the anti-nutritive factors, due to the high $\mathrm{pH}$ used [109,111].

Extrusion, solvent extraction and biological, thermal, or microwave treatment are various methods used to reduce or remove cyanogenic glycosides. The heat hydrolyzed the latter in hydrogen cyanide, which is then evaporated [114].

Phytates and tannin levels in sesame oil cake can be reduced by fermentation with Lactobacillus acidophilus, after which it can be used as feed in the diets of Labeo rohita [67]. Tannins from groundnut oil cake can be removed through solid-state fermentation (SSF) with the help of Pichia kudriavzevii, a process that also enhances its chemical properties [115]. The same process with Rhizopus oligosporus DSM 1964 and ATCC 64063 was performed for flaxseed press-cake to reduce phytate by $48 \%$ and 33\% respectively, and which enhances the bioavailability of calcium, magnesium, and phosphor by $14 \%$, $3.3 \%$ and $4 \%$ [116].

Methods for glucosinolates removal in canola are: extraction of protein based on protein micellar mass formation with minimal loss of proteins (ultrafiltration because the toxic compounds have low molecular weight than proteins), heat treatment (reduction of $94 \%$ and improved flavor and palatability), use of enzyme (pectinase, protease, hemicellulase), application of organic solvent (ethanol, methanol, and acetone). During the traditional extraction of proteins, the amount can be reduced due to the dilution process during washing $[22,110]$.

\section{Possible Ways to Capitalize the by-Products Obtained from the Oil Industry}

The most conventional practices of disposal/capitalizing oil cakes are: animal feed, landfilling, and biofuel conversion. They can be used as animal feed due to the rich content in protein (suitable for omnivore), cellulose, and hemicellulose (suitable for ruminants). Unfortunately, the presence of toxic compounds (with antinutritive effects and unbalanced nutrients) can affect both animals and humans. In landfilling, the decomposition of wastes leads to the production of methane and to water pollution. For these reasons, governments are trying to reduce landfilling through regulations (that impose the following measures: landfill prohibition, taxes, development of alternative solutions, and development of infrastructures), and public awareness. Food wastes contain organic compounds that can be converted first in energy through incineration. Increasing concerns about the high cost and negative impact on the environment due to the emissions [4,5].

The creation of a sustainable food chain and the increasing environmental issues lead to new valorization methods that imply the recovering/recapturing of valuable components, production of functional ingredients, development of new products and biopolymer films [4].

\subsection{Extraction of Bioactive Compounds}

Industrial residues contain valuable compounds (pigments, fibers, minerals, antioxidants) that can be reintegrated in the food industry and other fields (agriculture, cosmetics, pharmaceutics) [117]. Their extraction is done in three stages. The first step is pretreatment, which helps remove microbes from materials without affecting biological activities, using the following methods: foam mat, electro-osmotic, de-watering, and micro-filtration. The second step is extraction that can be realized through classical (solvents alone or mixed together, maceration, steam distillation) or advanced/novel/greener methods: extraction with water or ethanol, pulsed electric field, super/subcritical fluid extraction, enhanced solvent extraction, use of mixture water/organic solvent with dioxide carbon, accelerated solvent extraction, microwave/ultrasound-assisted methods and high voltage electric discharge, enzyme-assisted extraction. Moreover, these green, sustainable and innovative methods present some advantages and drawbacks. Advantages in using modern techniques are: high-quality extraction, selectivity in recovery, use of a small volume of solvent, a small amount of waste remained, environment friendly and less extraction time. Further, they provide a way to use wastes and by-products in industrial applications, based on the sustainable circular economy concept. 
The main drawbacks are high-energy consumption when using microwaves, separation issues in ultrasonic extraction, and lack of user-friendliness in the pulsed electric field. Traditional methods require long time extraction and large quantities of expensive, toxic, and hazardous solvents but respect of the novel ones have better efficiency reproducibility, efficiency, and extract manipulation. The final step implies purification with alcohol precipitation, ultrafiltration, or chromatographic technique [118-120].

From oil press-cakes and meals can be extracted high-value components such as proteins, antioxidants, phytochemicals, and dietary fiber [118].

\subsubsection{Protein Isolate, Concentrate and Hydrolysate}

Every year, the world population increases creating an increasing demand for food supply and proteins. Oil cakes/meals are a suitable alternative because they are a valuable source of proteins [111]. Plant proteins, recently, became an alternative for replacing those from animal sources because they are versatile, easily digestible, non-toxic, and nutritional sufficient. Moreover, the isolation process is less costly [121]. However, usually they lack sulfur amino acids and can negatively influence the flavor, color, and texture of foods [17].

Of all plants, proteins from rapeseed contain a large amount of S-amino acids (in an amount that exceeds the requirement for adults and children) and in terms of nutritional value can be compared with those from soy [122]. Napin and cruciferin are the dominating proteins groups (together $85-90 \%$ ) in rapeseed. Proteins recovered from cold-pressed rape oil cake have higher recovery yield and emulsion properties compared with those extracted with hot-press and solvents. In the recovery process, when the heat was applied the recovery-yield improved slightly $(p<0.05$, however only for solvent extracted rape oil cake. Conversely, the ability to stabilize emulsion decreased [22]. Soybean and groundnut contain proteins that can be easily absorbed, digested and are nutritionally equivalent to animal protein, the amount is $20-26 \%$ and covers the recommended daily dose for adults and children. Regarding the amino acid profile, soybean lacks methionine, and groundnut is rich in arginine. The proteins from linseeds are comparable with those from soya and are also rich in glutamic and aspartic acid and arginine. Furthermore, those from flaxseed have antifungal properties $[22,53,123]$. In hemp oil cake they are present two main proteins, histidine and albumin (a high amount of essential amino acids, especially arginine) comparable with those from egg and soy [17].

Press-cakes/meals are used to prepare protein isolates (with a content of proteins $>90 \%$ ), concentrates (with 30-80\%) and hydrolysates (resulted from the hydrolysis of protein isolates) [22]. By first solubilizing protein with alkali at a high $\mathrm{pH}$, then isoelectric precipitation with acid, washing, and drying the isolates are prepared. The isolates present high water-holding capacity and emulsifying activity and stability. They find application an as emulsifier and functional food (food and texture retainer and food system size expander) [53]. Proteins isolated from canola by the alkali method are not suitable as food ingredients because they have poor technological properties and solubility. Furthermore, during the process an irreversible denaturation takes place. For this reason, they need chemical or enzymatic improvement [110]. Those obtained from flaxseed and sesame are highly soluble in acidic and alkaline $\mathrm{pH}$ with good functional properties such as water holding and fat absorption capacities, emulsifying and foaming properties, bulk density, and poor gelling capacity [68]. Salgado et al. used sunflower oil cake and different procedures to obtain protein concentrates and isolates with high solubility $(75 \%)$. These were then subjected to extraction with various solvents (water, ethanol 70\%, methanol 80\%, acidic butanol, and sodium thiosulfate $0,1 \%$ ) to remove phenolic compounds and/or isoelectric precipitation. The residual phenolic compounds (remaining due to the association with proteins) confer to the final products antioxidant properties (without affecting water solubility) and a strong dark coloration (that could limit their potential application) [101].

Hydrolysates resulted from the hydrolysis of protein isolates: the protein structure is modified resulting in improvements of their functionality, solubility, surface activity, hydration, and gelling properties. Through this process, a fragment of protein is created known as a bioactive peptide 
with biological activity and a positive impact on human health (antioxidant, antithrombotic, hypercholesterolemic, bile acid binding and immunomodulatory activities). These changes depend on the type of enzyme used and the degree of hydrolysis. Peptides with antihypertensive and antioxidant activity and high digestibility are developed by subjecting the sesame oilcake/meal hydrolysate to an additional process of hydrolysis with alcalase, papain, and pepsin [22,124]. Protein hydrolysates from canola can be used in enhancing cooking yield, water holding capacity, and organoleptic attributes in meat formulation. Furthermore, enzymatic hydrolysates can be used for the formulation of a flavor with meat characteristics [125]. Rapeseed bioactive peptides in concentrations between 30 and $50 \mathrm{mg} / \mathrm{L}$ inhibit thrombosis activity up to $90 \%$. They also have antioxidant properties (malondialdehyde inhibition by $50 \%$ in blood serum, inhibition of lipid peroxidation), blood pressure regulation capacity (a peptide called rapakinin induced vasorelaxation), and bile acid-binding capacity. Peanut peptide instead has high antithrombotic activities [125-127].

Kavitha. et al. [128] use sesame seed cake for the production of vegetable peptones. On a media containing protein hydrolysates, yeast extract, sodium chloride, and agar were carried out morphological and growth analysis of different organisms (Candida albicans, Bacillus subtilis, Escherichia coli, and Saccharomyces cerevisiae). On the vegetal peptone, both prokaryotes and eukaryotes present higher microbial growth and thus can act as a replacement for those of animal origin. Some advantages were observed: vegetal peptone can be used for the production of amylase and the yeast produced has a short fermentation time.

Protein concentrates from rapeseed have poor gelation ability than soybean that can be improved by glutaminase enzyme [129]. Results also showed that presents darker color, lower purity, and yield (due to the wide range of isoelectric points) [130]. Sensory evaluation of sausages, formulated with canola protein concentrate in place of casein demonstrated that improves taste, texture, and aroma [125]. Sesame protein concentrate introduced in the proportion of $10 \%$ in extruded snacks lower the carbohydrate content and enhance organoleptic properties, color, and protein content [131].

\subsubsection{Antioxidants}

Oil cakes/meals contains free, esterified or condensed form of phenolic acids, flavonoids and lignans that help in reducing oxidative stress and thus preventing various types of cancer. They can be extracted with solvent (it can be used organic solvents, alone or mixed together or non-toxic solvents such as water, but these need to be combined with other mild extraction techniques), high pressure, microwave, and supercritical fluid. Antioxidants extracted in this way can be used in the preparation of foods (beverages, energy bars, bakery, and extruded products) [22,118]. The major antioxidants in oil cakes are presented in Table 3. The antioxidative activity in soybean cake/meal is due to isoflavones and cinnamic acid derivative and for groundnut cake/meal, phenolics, caffeic, and chlorogenic acids. Phenolic compounds are the principal antioxidants in rapeseed, coconut, sunflower, mustard, sesame and cotton cakes/meals [22].

Fermentation helps to improve the nutrient levels of oil cake, because during the process a microbial synthesis of biomolecules takes place. Following this idea, Stodolak et al. [132] observed that in flaxseed oil cake fermented for $48 \mathrm{~h}$ with Rhizopus oligosporus DSM 1964 and/or ATTC 6403 there was an increase of $13-85 \%$ in phenolic levels and a decrease in scavenging activity by $20-30 \%$. The same results were obtained when peanut oil cake was fermented for $120 \mathrm{~h}$ with Aspergillus awamori [133]. Another treatment useful in enhancing antioxidant capacity involves the use of ultrasound. Maximum polyphenol content was obtained when the treatment time was $20 \mathrm{~min}$ and with the temperature at $70^{\circ} \mathrm{C}$. The high heat is able to break the bonding between the phenolic compounds and matrix, modifying the structure of plant membranes and causing lipoproteins coagulation. Furthermore, prolongation of exposure means that the ultrasonic wave divided the phenolic extract in longer periods [134].

Cold-pressed cake from walnut is a source of natural antioxidants. Bakkalbași [135] extracted phenolic compound from walnut pressed cake. This extract was added in different concentrations 
$(50,100$, and $200 \mathrm{mg} / \mathrm{kg})$ to increase the oxidative stability of walnut oil. The highest result was obtained with the addition of $200 \mathrm{mg} / \mathrm{Kg}$. When oilcake is added directly to oil (1:100) through ultrasonic maceration the oxidative stability decreases although the amount of total phenolic compounds increased. This may be caused by free fatty acids (created in sonification) with a pro-oxidative effect.

The cake obtained from sesame oil contained bioactive compounds such as phytochemicals with numerous benefits (phenolic compounds, flavonoids, tocopherols, vitamins, pigments, steroids, carotenoids, and lignans) for health. Lignans such sesamin, sesamolin, sesamol, and sesaminol glucosides have the following effect: anticarcinogenic, antiproliferative, antioxidant, antimicrobial, anti-inflammatory, antidepressant, neuroprotective, and hypocholesterolemic activities [136]. Sesame meal introduced in concentrations ranging from 5 to $200 \mathrm{ppm}$ acts as a stabilizer for sunflower and soybean oil, by inhibiting double bond conjugation, thermal deterioration, and losses of polyunsaturated fatty acids. Furthermore, in high concentrations, the efficiency is equivalent to butylated hydroxy anisole and butylated hydroxy toluene. Products were introduced to an oven temperature of $70{ }^{\circ} \mathrm{C}$ for $72 \mathrm{~h}$ and subjected to oxidation in the dark, and a protective effect was observed during the initial and final steps. This activity is attributed to the phenolic compounds and their redox properties (extinguish singlet and triplet oxygen, decompose peroxides, adsorb, and neutralize free radicals) [61,137]. Reshma [74] analyzed the potential of using defatted sesame cake to inhibit two digestive enzymes ( $\alpha$-amylase, $\alpha$-glucosidase). The result exhibits a strong inhibitory potential for $\alpha$-amylase and mild for $\alpha$-glucosidase, due to the presence of phenolic compounds and flavonoids. These modulate the enzymatic decomposition of carbohydrates by inhibiting glucosidases and amylases.

Natural phenolic antioxidants (flavonoids, phenolic acids) from sesame and coconut oilcake and synthetic butylated hydroxytoluene (BHT) were introduced in vanilla cake composition to compare their potential in improve the oxidative stability and both microbial and chemical shelf-life, without changing consumer acceptability. Both oilcakes improved chemical and microbiological stability up to 13 days, and only up to 11 days for BHT. The sensory quality in cakes with by-products from the oil industry was retained from the first day to day 12 . Moreover, the activity of natural antioxidants is stable thermally [137].

Sesame oilseed cake extract (lignans) at a lower amount (150 ppm) can be used as a food additive with a role in oil stability improvement. In butter, it can reduce the lipid oxidation time much better than BHT without changing the sensory properties $[57,136]$.

Table 3. Antioxidants in oil cakes.

\begin{tabular}{ccc}
\hline Antioxidants & Oilcake & Reference \\
\hline Gallic acid & Canola & {$[111,136,138]$} \\
Tannic acid & Linseed & {$[111]$} \\
p-coumaric & Flax, Peanut, Sunflower, Linseed, Sesame, & {$[111,136,138]$} \\
Catechin & Mustard, Rapeseed, Palm, Olive & {$[111,136,138]$} \\
Caffeic acid & Canola/ Rapeseed, Sunflower & {$[111,136,138]$} \\
Epicatechin & Canola/Rapeseed, Hemp, Peanut, Mustard, Palm & {$[111,136,138,139]$} \\
Ferulic acid & Canola/Rapeseed, Sunflower & {$[111,136,138]$} \\
Quercetin & Canola/Rapeseed, Flax, Linseed, Sesame, & {$[111,136,138]$} \\
Luteolin & Cottonseed, Mustard, Palm & {$[111,136,138]$} \\
Lignans & Hemp, Canola/Rapeseed, Cottonseed, Olive & {$[136-141]$} \\
Chlorogenic acid & Hemp, Canola/Rapeseed, Olive & {$[136,139]$} \\
Sinapic acid & Sesame, Olive, Linseed & {$[125]$} \\
p-hydroxybenzoic acid & Sunflower & {$[136]$} \\
\hline
\end{tabular}




\subsubsection{Dietary Fiber}

Dietary fiber (DF) is defined as a group of carbohydrate polymers (oligosaccharides and polysaccharides) that cannot be hydrolyzed (digested and absorbed) in the small intestine by human digestive enzymes [142]. In this category are included insoluble components (cellulose, hemicelluloses, lignin), soluble components (gums, pectin substances, mucilages), inulin, and resistant starch [143,144]. DF has different functions and effects, depending on the physicochemical properties. For example, DF with high water-holding and/or swelling capacities reduce defecation time and produce satiety, on the other hand, those with high binding activity hinder DNA and epithelial cell damage [76].

A diet rich in dietary fiber brings many health benefits, such as reducing the risk of coronary heart disease, cancer, obesity, and diabetes. In the food sector DF is used to improve nutritive, organoleptic (color, flavor, taste), and textural properties (increasing water/oil holding, emulsion, or/and gel formation capacities and avoiding syneresis). They can also prolong the shelf life and improve oxidative stability [76]. Recovery and utilization of fiber from wastes represent key factors in implementing a sustainable production (they have health benefits, are available in large quantities, have low cost and are environment friendly), zero wastes, and circular economy [119,145].

DF can be extracted through different methods: traditional (dry/wet processing, chemical, enzymatic gravimetric, microbial) and green/innovative extraction (with ethanol, water, steam, ultrasonic, hydrostatic pressure, and pulsed electric field). The method used can influence the composition, trait, and behavior (in food and human body) of DF. From the first category, the most rentable, effective (purity of final product $50-90 \%$ ) is wet processing. The utilization of alkali/acid can damage the structure and through enzymatic path the extraction can be incomplete. The innovative methods present advantages such as high recovery rate and low environmental impact $[119,143]$.

Dietary fiber extracted from by-products can be used in foods and pharmaceutics as a functional ingredient, supplements, or additive [144]. Zheng and Li [76] studied how particles size, extraction with cellulase, and acid treatment affect the structure and properties of the dietary fiber from coconut oil cake. Reduction of the first factor (particle size) led to an increase in entrapment, water holding, and swelling capacities. The cellulase hydrolysis had an undesirable effect on color and oil holding capacity but increased carbohydrate content, porosity, water holding, swelling and alpha-amylase inhibition capacities. Compared to the previous (cellulase hydrolysis), the last parameter (acid treatment) led to inverse results.

\subsection{Substrate for Functional Ingredient Production}

Wastes from the oil industry can be used as substrate for the production of enzymes, antibiotics, biopesticides, biofertilizers, aroma compounds, pigments, vitamins, biosurfactants, and mushrooms due to their low cost, accessibility, and nutrient composition that require small or no supplementation. These are called functional ingredients and have important benefits for consumers [22].

Their production can be realized with a submerged fermentative medium (SFM) or solid-state fermentation (SSF). The first method involves the use of a liquid substrate rich in various nutrients for microbial growth. Unfortunately, the substrate is used rapidly and needs to be supplemented constantly [79]. The second one is a process in which an organism (fungi, yeast, and bacteria as single or mixed cultures) is grown on a moist solid substrate, in an environment with low or nil water content. The microorganisms, in the presence of an abundant substrate (glycerol, glucose, or carbon source) are opposed to the catalytic processes (inhibition of enzyme synthesis). It presents various advantages such high-stability and productivity, reduction of cost process, energy, and pollution [146,147].

\subsubsection{Enzymes}

Various enzymes have an important role in industrial application. They can be produced by solid-state fermentation using oil cakes/ meals as substrate, because they are cheap materials (reduce the cost production) rich in nutrients, carbon and nitrogen and are compatible for fungal 
species. Some examples are tannase, inulinase, $\alpha$-amylase, glucoamylase, protease, phytase, mannase, lipase and L-glutaminase (Table 4). Their production depends on incubation time and $\mathrm{pH}$, moisture and particle sizes of substrate. Large particles and too much content in water prevent the digestion of raw material and microbial respiration which leads to poor growth and enzyme production [148].

Proteases are a group of enzymes with a role in the protein hydrolysis. Bacterial and fungal species such as Bacillus horikoshii, Bacillus clausi I52, Penicillium sp., Candida utilis, Bacillus sp. 1-312, Aspergillus oryzae (NCIM No.649, NRRL 1808), Streptomyces termovulgaris were used for protease production with soybean (overheated), coconut, olive, palm, sesame and rapeseed oilcakes/meals as substrates [81,148]. Gupta et al. [149] studied the ability of non-edible Mahua and Jastropha cake to act as substrates for Aspergillus niger and Paecilomyces variotii growth and produce enzyme. The study concluded that despite the low protease activities, solid-state fermentation is suitable in antinutrient removal.

Lipases are hydrolytic enzymes with numerous applications in the pharmaceutical and cosmetic industries and in dairy and bakery foods. Parihar et al. [147], Oliveira et al. [50] optimized the production of lipase through SSF with Pseudomonas aeruginosa and Aspergillus ibericus. The highest production was obtained when the substrate used resulted by combining two oilcakes: linseed/ olive and sesame/ palm kernel. The obtained enzyme can be used in esterification (butyl decanoate formation using 5\% biocatalyst) and hydrolysis reactions (increase production in shorth-chain triacylglycerols). Lipase extracted from Rhizomucos pusillus, Rhizopus rhizopodiformis and Pseudomonas sp. S1 cultivated on olive oil cake, are suitable for oily waste water treatment and biodiesel production [150]. The enzyme could be extracted also from Penicillium simplicissimum, Candida rugosa, Penicillium Chrysogenum $\mathrm{S}_{1}$, and Candida utilis inoculated on soybean, coconut, sesame and olive oilcakes $[81,147,151]$.

L-asparaginase is an enzyme that can be used as a drug, due to its therapeutic effect against leukemia. A content of $90.025 \mathrm{IU}, 310 \mathrm{U} / \mathrm{gds}$ and $5.75 \mathrm{U} / \mathrm{gds}$ was obtained in solid SSF from Aspergillus wentii NCIM 941, Aspergillus niger C4 and Serratia marcescens, cultivated respectively on palm, sesame oil and coconut cake $[63,152,153]$.

$\alpha$-amylase used in starch liquefaction was produced from Aspergillus oryzae, Aspergillus terreus UF39 cultivated on two oilcakes: coconut and groundnut [79,147].

Phytase, and glucoamylase have been produced using bacterial and fungal species such as Bacillus licheniformis, Aspergillus ficuum, and Thermomucor indicae-seudaticae respectively growing on sunflower, rape/canola, and cotton oilcakes as substrates in solid state fermentation [10].

Xylanase, xylosidase, acetyl-xylan esterase and cellulase were produced in a SSF process with rapeseed/canola oilcake as the substrate, on which microorganisms such as Trichoderma reesei and Streptomyces termovulgaris were grown. Alternately, Aspergillus oryzae produced protease, phytase and phosphatase $[10,89]$.

L-glutaminase and phytase were produced using sesame oilcake as substrate and microorganisms such as Zygosaccharomyces rouxii, Mucor racemosus and Rhizopus oryzae [151].

Use of coconut oilcake as a nutrient source grew a bacterial strain of Staphlococcus sp. and fungal species such as Aspergillus ficuum, Mucor racemosus, Rhizopus oryzae, Rhizopus oligosporus and Aspergillus niger to produce inulase, phytase, and glucoamylase [22,82,147].

Lomascolo, et al. [10] reported the production (through submerged culture medium and SSF) of alpha-amylase and endoxylanase when using sunflower meal. The first one is obtained from Bacillus licheniformis and the second one from Humicola lanuginose. 
Table 4. Production of enzymes through solid state fermentation using as substrates oil cakes.

\begin{tabular}{|c|c|c|c|}
\hline Enzyme & Oilcakes & Microorganism & Reference \\
\hline \multirow{5}{*}{ Lipase } & Coconut & Penicillium simplicissimum, Candida Rugosa & {$[147,151]$} \\
\hline & Sesame & Penicillium Chrysogenum & [151] \\
\hline & Olive & $\begin{array}{l}\text { Rhizomucos pusillus, Pseudomonas sp1, Rhizopus } \\
\text { rhizopodiformis, Candida Utilis }\end{array}$ & {$[81,150]$} \\
\hline & Soybean & Penicillium simplicissimum & [147] \\
\hline & Cotton & Penicillium strain $X$ & [151] \\
\hline \multirow{10}{*}{ Protease } & Flaxseed-Olive & Pseudomonas aeruginosa & [147] \\
\hline & Sesame-Palm kernel & Aspergillus ibericus & [50] \\
\hline & Soybean & Bacillus horikoshi & {$[81,148]$} \\
\hline & Coconut & Bacillus clausi I52 & {$[81,148]$} \\
\hline & Palm kernel & Bacillus sp. I312 & {$[81,148]$} \\
\hline & Sesame & $\begin{array}{c}\text { Aspergillus oryzae NRRL 1808, Aspergillus oryzae } \\
\text { No. } 649\end{array}$ & {$[81,148]$} \\
\hline & Olive & Penicillium sp., Candida utilis & [81] \\
\hline & Mahua & Aspergillus niger & [149] \\
\hline & Jastropha & Paecilomyces varioti & [149] \\
\hline & Rapeseed & $\begin{array}{l}\text { Aspergillus ficuum, Streptomyces thermovulgaris, } \\
\text { Aspegillus oryzae }\end{array}$ & [151] \\
\hline \multirow{3}{*}{ Phytase } & Coconut & $\begin{array}{l}\text { Aspergillus ficuum, Rhizopus oligosporus NRRL } \\
\text { 5905, Mucor racemosus, Rhizopus oryzae }\end{array}$ & [151] \\
\hline & Sesame & Mucor racemosus, Rhizopus oryzae & {$[22,82,151]$} \\
\hline & Canola/Rapeseed & Aspergillus ficuum, Aspergillus oryzae & {$[10,22,82]$} \\
\hline \multirow{3}{*}{$\alpha$-Amylase } & Coconut & Aspergillus oryzae, Aspergillus terreus UF39 & {$[79,147]$} \\
\hline & Sunflower & Bacillus licheniformis & {$[10]$} \\
\hline & Groundnut & Aspergillus oryzae & {$[79,147]$} \\
\hline \multirow{2}{*}{ Glucoamylase } & Coconut & Aspergillus niger & {$[22,82]$} \\
\hline & Cotton & Thermomucor indicae-seudaticae & {$[10]$} \\
\hline \multirow{3}{*}{ L-Asparaginase } & Sesame & Aspergillus niger & {$[152]$} \\
\hline & Palm & Aspergillus wentii & [63] \\
\hline & Coconut & Serratia marcescens & [153] \\
\hline L-Glutaminase & Sesame & Zygosaccharomyces rouxii & [151] \\
\hline Inulase & Coconut & Staphylococcus sp. & {$[22,82,147]$} \\
\hline Xylanase & Rapeseed & Trichoderma reesi & {$[10,89]$} \\
\hline Endoxylanase & Sunflower & Humicola lanuginosa & {$[10]$} \\
\hline Phosphatase & Rapeseed & Aspergillus oryzae & [151] \\
\hline
\end{tabular}

\subsubsection{Mushrooms}

A possible valorization of agro-industrial by-products is in mushroom cultivation. Mushrooms with good antioxidant properties were produced by SSF, using oil cakes as substrate. Moreover, some nutrients may transfer during the growth making them, food with therapeutic properties and high nutritional value. For example, Lentinula edodes, Ganoderma lucidum, and Grifola frondosa are hepatoprotective, antidiabetic, anticholesterolemic, and immunologic [154,155].

Krupodorova, et al. [156] investigate the possibility of using alternative and cheap substrates (wastes from the oil industry) for mycelial growth of 29 mushroom species. Oilcakes studied were those obtained from walnut and soybean, rape, sunflower, linseed, pumpkin, and mustard seeds. Soybean and walnut oilcakes were found respectively most and least suitable for mushroom growth (24 and 2 species respectively out of 29). Low results were found also for mustard and pumpkin ( 6 and 8 species). These may be due to the composition (small amount of proteins and high amount in lipids; deficiencies in essential nutrients) and $\mathrm{pH}$ of the substrate. The replacement of peptone with sunflower cake led to the growth of 12 out of 29 species of mushroom, more precisely to Ganoderma lucidum and Laetiporus sulphureus species. Linseed/flaxseed cake supported 13 species of mushroom growth including the Pleurotus species, results that was observed also by Jape, et al. [157].

Gregori and Pohleven [154] tested how different proportions of olive oil cake influence the production of Ganoderma lucidum, Lentinula edodes, and Grifola frondosa. The mushroom production decreased with the increase in proportion, they also change in color and deformed (content $>40 \%$ ). The same negative effect was observed with Pleurotus ostreatus, Pleurotus eryngii, Pleurotus pulmonarius, 
Pleurotus cystidiosus and Agrocybe cylindracea species (content $>60 \%$ ). This was probably due to the presence of polyphenolic compounds and low porosity, substrate aeration, and water retention capacity $[158,159]$.

\subsubsection{Antibiotics}

Antibiotics are defined as substances produced by microorganisms with the ability at low concentration to inhibit/kill other microorganisms. Oilseeds cakes can be used as a substrate for various antimicrobial agents and antibiotics production, doing so also reduces the cost [22,160].

Sunflower, soybean, and sesame meal were used for the production of clavulanic acid and cephamycin C and by SSF with Bacillus licheniformis for endotoxin and bacitracin. The maximum synthesis of the latter was found in soybean meal [22,160-162].

Neomycin is a low toxic antibiotic used in tuberculosis, wound injury, and skin diseases. It was extracted by SSF process from Streptomyces fradiae NCIM 2418, grown on coconut cake [163].

Rifamycin is a broad-spectrum antibiotic with the ability to inhibit RNA- dependent DNA polymerase, commercial fermentation process with industrial strain generates only rifamycin B (modest activity) that can be chemically converted to rifamycin SV (a direct derivate product of rifamycin, it is also more efficient). The latter was isolated in SSF from Amycolatopsis mediterranei OVA5-E7. The maximum production was observed on the de-oiled cotton cake, followed by mustard, sunflower, groundnut, coconut, and sesame de-oiled cake [164]. Vastrad, et al. [163,165] also extracted rifamycin B (it is very powerful, easily biodegradable, and less toxic) from Nocardia mediterranei MTCC14 growth on sunflower oil cake and Amycolatopsis mediterranei MTCC14 growth on coconut and groundnut cake.

Sunflower meal can act as a substrate in the production of two antibiotics. Clavulanic acid with broad-spectrum antibacterial activity and potent $\beta$-lactamases inhibitor could be obtained in a solid-state fermentation process by Streptomyces clavuligerus. Cephamycin $C$ was successfully achieved in both submerged culture medium and solid-state fermentation (SSF), the meal served also as $\mathrm{pH}$ regulator and foam controller [10]. From Bacillus subtilis grown by SSF with rapeseed meal, $5.3 \mathrm{~g} / \mathrm{Kg}$ of iturin $\mathrm{A}$, and $51.3 \mathrm{~g} / \mathrm{Kg}$ of poly- $\gamma$-glutamic acid were obtained in about $90 \mathrm{~h}$ of fermentation [166].

\subsubsection{Biosurfactants}

Surfactants are amphiphatic molecules (derivate from petroleum compounds) composed of a hydrophilic and hydrophobic group that decrease interfacial and surface tension with water/hydrophobic systems. When synthesized by different microorganisms they are called biosurfactants with numerous advantages over the synthetic ones: low toxicity and good biodegradability, biocompatibility, chemical diversity, and stability. Based on chemical composition they are divided into glycolipids, lipopeptides, lipopolysaccharides, and oligosaccharides. Examples include rhamnolipids, trehalolipids, sophorolipids, mannosylerythritol lipids. Due to these properties they can be used in the environmental sector (bioremediation of pesticides, oil, and heavy metals, enhanced oil recovery, antimicrobial agents and biopesticides), petrochemicals, cosmetics, food, agriculture, and pharmaceutics [167-169].

Sophorolipids, microbial biosurfactants used in detergents and cosmetics formulation, were synthesized by Starmerella bombicola growth on residual sunflower cake through SSF. Their effectiveness is equivalent to Triton X-100, that is a considerate environmental pollutant [170].

Thavasi et al. [171] cultivated Lactobacillus delbrueckii and Pseudomonas aeruginosa on peanut oil cake for the production of biosurfactants (glycolipids and lipopeptides) with potential use in biodegradation of crude oil and in bioremediation of hydrocarbon pollution environments. Another example of biosurfactant (rhamnolipid) utilized for this purpose was synthesized from Ochrobactrum anthropi cultivated on palm oil decanter cake [168,172].

In the pharmaceutical and food industries surfactants from Enterobacter sp. MS16 cultivated on sunflower oil cake can be utilized as fungal inhibitor [95]. Antibacterial and antifungal activities were shown by lipopeptide from Brevibacterium aureum MSA13 cultivated on olive/safflower oilcake. 
Glycolipids obtained from Lactobacillus delbrueckii on peanut cake also has good foaming and emulsion capacity and for this reason, can be used in emulsion food [22].

Lipopeptides are biosurfactants isolated from Bacillus pseudomycoides OR1 cultivated on groundnut oilcake and can be used for their antibacterial activity against foodborne, pathogens. At $50 \mu \mathrm{g} / \mathrm{mL}$ they inhibit Escherichia coli, Staphylococcus aureus and Klebsiella pneumoniae. They bind to the bacterial surface, modifying the lipid organization by changing fatty acids and thus preventing cellular processes [173].

\subsection{Animal Feedstuff}

A possible valorization of the residues resulted from oil extraction process is in animal feedstuff. Their utilization can be limited by: seasonal production (that can lower spatial and temporal availability), low levels of nutritive components, presence of toxic compounds (with possible negative effect on animal performances), and composition variability (diet formulation becomes difficult). This valorization strategy improves economy, and environment sustainability. Oil cakes rich in fat and proteins can be suitable for feeding omnivores, while those with high cellulose content for ruminants $[4,99]$. Soybean oilcake may be used primely in the diet of monogastric species (chickens and pigs), palm oilcake in ruminants, rapeseed, sunflower, and pumpkin oilcakes in pigs [174].

Ensuring durable and economic fish farming involves the use of fishmeal substitutes. Different studies investigate the possibility to use oilcakes as feed in aquaculture. Pellets were produced by replacing $25 \%$ of the reference fishmeal with rapeseed, sunflower, soybean, and linseed press-cakes. The products obtained had similar nutritional values to the reference with high sedimentation velocity and less water stability, abrasion resistance, and expansion. This can be improved by using finer milled particles and altering the screw configuration of the extruder [21]. Nang et al. [175] observed that the replacement of fish meal with sesame press-cake (without amino acid supplementation) up to $52 \%$ did not reduce rainbow trout growth performances. The feed cost can also be reduced and made more sustainable. The performance of mustard and soybean press-cake in fish production was analyzed. The first cake led to poorer growth and food conversion ratio, but the second one is advantageous for crap breeding [93]. Fish meal can be replaced also with solid state fermented oilcakes, this process increases the levels of amino acids and decreases crude fiber content and antinutritional factors. Fermented soybean meal $(200-400 \mathrm{~g} / \mathrm{Kg})$, sunflower cake $(0-100 \mathrm{~g} / \mathrm{Kg})$ and groundnut oilcake $(20-50 \%)$ were used in different levels as a replacement to fish meal in the diets of shrimps and carps. The inclusion up to $325.1 \mathrm{~g} / \mathrm{Kg}, 32.6 \mathrm{~g} / \mathrm{Kg}$ and $40 \%$ respectively had no adverse effect on growth, carcass composition and feed utilization efficiency in comparison to the reference diets $[90,115]$.

In ruminants feeding is necessary to cover the nutritional needs (energy, protein and mineral intake) for animal production. Serrapica et al. [99] investigate the potential use of fifteen oilseeds cake (from hemp, sunflower, tobacco, cardoon and pomegranate) as protein supplements in their feeding. Of all this, hemp and tobacco oilcakes are the most suitable due to the high content in carbohydrate and slow degradable fractions of crude protein. Olive cake contains a low amount of proteins and considerable percentage of tannins, which makes it unpalatable and poorly digestible. In order to remove these antinutritional components and increase the protein content, olive cake was subjected to a biological process (SSF). The cake was inoculated with four fungi (Beauveria bassiana, Rhizodiscina cf. lignyota, Aspergillus niger and Fusarium flocciferum) for 15 days. Results showed a significant $(p<0.05)$ increase in proteins (94\%) and decrease in phenolic compounds (43\%), flavonoids (70\%) and condensed tannins (42\%) due to the production of enzymes (oxidases, peroxidases) by fungi [176].

In dairy sheep feed concentrate, two levels of oil cake (rapeseed and sunflower) inclusion $(50 \%$ in winter and $30 \%$ in spring) did not affect the cheesemaking (crude fiber/crude protein ratio) or milk production parameters. Analysis on the milk showed that in winter, when the pasture is unavailable, the amount of healthy fatty acid increased [37]. Satisfactory carcass yield and feedlot performance (body weight gain, feed conversion efficiency) also were observed with the addition up to $20 \%(300 \mathrm{~g})$ of groundnut and sesame oilcakes $[177,178]$. Sesame meal also improved intake, digestibility and rumen condition in lambs without changing performance and carcass composition [179]. 
In adult male goats, the incorporation in a concentrate mixture of walnut oilcake up to $10 \%$ did not have negative effects on the calcium and phosphorus balance, however the high amount in aminotransferase may cause hepatotoxic problems [180]. Similar results were concluded by Mir [86], furthermore the level of oilcake $(<10 \%)$ did not affect total gas production, efficiency biomass production, in vitro digestibility of dry matter, microbial biomass production and true degradable organic matter.

Chipa et al. [181] evaluated the possibility of incorporation soybean press-cake, in proportions of $0-20 \%$, as a source of proteins in the diets of beef cattle. The experiment was conducted on 20 heifers and 20 steers for a period of 98 days. At the end of the treatment the steers were heavier that the heifers, due to the high feed intake and conversion ratio. An increasing in growth was observed in the diet with $6 \%$ and $13 \%$.

\subsection{Applications in Food Products}

New food products can be developed with two categories of ingredients: firstly, it includes new, alternative, and never used before on a regular basis in food products and secondly, they are obtained by the valorization of by-products. Their successful implementation can be achieved by creating a marketing strategy. This involves new regulations, customer education and clear transparency (better communication, adequate labeling) [182]. Introduction to the food of ingredients with important benefits for consumers (functional ingredient) is called functional [22]. Residues from the oil industry could be used as co-products for high value-added products, food additive, or supplements [71]. Bochkarev, et al. [24] studied the physicochemical composition of four oilcakes, and they divided them into three groups. In sesame oilcake, which is used for enrichment, proteins and lipids dominate. When proteins and carbohydrates dominate in oilcakes (in the case of pumpkin and walnut), it can be used as fillers in dairies and meat. A possible use of oilcakes rich in proteins and fibers (flax) can be found in bakery and confectionery.

Four different cold-pressed cakes (coconut, flax, sunflower, pumpkin) were mixed and then compacted to create tablets with functional properties, that can be used as supplements. When coated with starch and enriched with honey, they have better hardness and resistance to cutting. These tablets can be directly consumed if coated with various flavors as chocolate or caramel [77].

Application of treatments on oilcakes made them more appealing, palatable, edible, and suitable for human consumption as supplements. In this regard, coconut and sesame cakes were mixed with water and cooked so that the solid part can be separated from the liquid, and then subjected to drying. After that, the nutritional composition of the raw and cooked residue (solid and extract) was analyzed. Overall, the cooked residues retain more nutrients than the extract [21]. Starting from this premise, Sunil, et al. [183] used sesame and coconut solid cake for the formulation of four healthy foods. The first and third formulation contained coconut cake in proportions of $10 \%$ and $20 \%$. The other two, instead, contained $15 \%$ coconut and sesame cake. All foods were considerate acceptable in sensory evaluation.

\subsubsection{Bread}

The most consumed product is bread and can act as a vector for bioactive ingredients. For this purpose, Pycia K., et al. [184] incorporated walnut oil and oilcake $(1 \%, 3 \%, 5 \%)$ as a replacement for wheat flour. Increasing the level of oilcake enrichment led to harder, smaller (the replacement led to a decrease and weakening of gluten), darker and chewy bread, but with a high antioxidant potential compared to the control. Rheological properties of the dough with different ratios $(7.5 \%, 10 \%$ and, $12.5 \%$ ) of flaxseed oil cakes were studied in the Mixolab. As the levels increased the water absorption capacity increased, but the viscosity, amylolytic activity, and retrogradation decreased. All of these lead to a rapid dough maturation, thus reducing by 1.5 -times the total fermentation duration $[185,186]$.

\subsubsection{Biscuits}

Sesame oilcake flour was incorporated in five biscuits formulation $(0 \%, 10 \%, 25 \%, 50 \%$, and $75 \%)$ as a replacement for wheat flour. Products with white sesame oil cake (up to 50\%) did not change 
taste and texture, but at 75\% it becomes frail. Texture and taste of the first three biscuits formulation with black sesame oil cake were good. The last two formulations were produced after taste, but only the last one became brittle. With the previous incorporation, the diameter and weight loss (so the microbial contamination is reduced) were reduced, but the thickness, hardness, and fracturability increased. [71]. The same results were obtained when soybean and groundnut were used, due to the fact that high protein flours present high water retention and the biscuits cannot develop well. Unlike the previously analyzed products, these biscuits are considered acceptable at low-level incorporation. Regarding the rheological properties, the first oilcake increased the water absorption more, and the mixing characteristics of doughs. With the increasing proportion of the second oilcake (groundnut) the farinograph bandwidth increased but became slightly irregular. This led to an increase development of gluten protein and therefore of the dough consistency. The color of the final products become darker with the addition of the two oilcakes, due to the brownish and yellowish color of the raw materials used [187].

\subsubsection{Snacks}

On corn extrudate the addition of cold-pressed cake from sesame (0-20\%) caused an imbalance in the amino acid profile, reduced carbohydrates content and sectional expansion, and increased the protein, fat and ash contents. Products became more darker but were organoleptically acceptable, especially those with $20 \%$ [62].

Healthy, non-caloric, and high nutritional snacks can be achieved with the incorporation of food industry by-products rich in antioxidants, essential fatty acids, fiber, and minerals. Cottonseed meal was incorporated, by Jáquez, et al. [188], in corn extruded snacks at different levels (5-98\%) with a 10\% optimum. With the increase in oil meal the consumer acceptance decreases, the surface becomes rougher, lumpier, and disrupted. The same conclusions and optimum levels were found for rice/corn snacks when defatted flaxseed meal was incorporated [96]. In accordance with the first two studies related previously, a proportion of $5 \%$ defatted hemp oilcake can be successfully introduced in corn snacks. The level of acceptance is lower because of the high fiber content [108]. Radočaj, et al. [106] developed gluten-free snacks/crackers with hemp flour (from cold oilcake) and decaffeinated green tea leaves. All formulations were qualified as healthy (high minerals, fibers, and a desirable omega-6/omega-3 ratio) and are suitable for people suffering from celiac disease. The highest appreciation was achieved with the highest addition level.

\subsubsection{Desserts}

Macaron is a luxury and expensive dessert, and by adding walnut oilcake $(0-50 \%)$ their quality can be improved, and at the same time the production cost can be reduced. The improvements refer to the decrease in carbohydrates, omega-6/omega-3 ratio, and energy which is favorable in the problems associated with obesity, normal, and under nutrition. The addition strongly influences the amount of linoleic and caproic acid but not the aroma of macarons. However, the sensory analysis demonstrated that macarons with an addition of more than $10 \%$ were not appreciated, due to the increase in phenolic and volatile compounds that affect the taste [88]. Walnut oilcake can be introduced, at different levels $0-20 \%$, as a supplement in cake formulations. Increasing the addition, it led to a decrease in firmness, cakes become softer due to the high-fat content of press-cake. The substitution levels increase the total phenolic compounds and antioxidant ability but were not enough for increasing the proteins. Sensory evaluations demonstrated that cakes supplemented with $15 \%$ were the most appreciated. The crust color became lighter due to the addition of the skin portion of walnut [83].

\subsubsection{Dairy Products}

Increasing interest for new functional food, ideal different typologies of consumers such as vegetarian/vegan and with intolerance/allergy to dairies leads to the production of kefir-like fermented beverages using as substrate different levels of flaxseed cake $(5,10,15 \%)$. After the inoculation of kefir 
grains on the substrate, the mixtures were incubated for $24 \mathrm{~h}$ at $25^{\circ} \mathrm{C}$ and then stored at $6{ }^{\circ} \mathrm{C}$ for 21 days. Acid lactic and yeast grew well on flaxseed cake without any supplementation and their viability exceeded the recommended level for kefir products. With the increase in cake percent, the beverages had high viscosity (due to the presence of mucilage and protein), firmness (due to the production of polysaccharide kefiran), and antioxidant activity (due to the production of phenolic compounds and bioactive peptides). Another advantage is in the economic field; oilcakes are cheap, safe material available throughout the year [114].

\subsection{Biopolymer Packaging}

In order to improve the quality and shelf life of foods but also to minimize the petroleum derivates packaging residues, there were synthesized biodegradable polymeric materials [189]. Films and coatings are biopolymer packaging materials with the same chemical composition, but different appearance: the first ones are separate materials while the second ones are created on the surface of a product. The two processes used for films development are casting (or wet process) and compression/extrusion (or dry process). The most used is the first one and involves the dispersion of the forming macromolecules in an appropriate medium followed by solvent evaporation $[190,191]$.

Their applicability in packaging is influenced by the following properties: optical, thermal, mechanical (must preserve the integrity of packaged products, films must have high tensile strength and elasticity), structural, microbiological, sensory (should be tasteless, clean, transparent, odorless) and barrier (against aroma compounds, water, gas, and light permeability). The films have numerous advantages such biodegradability, biocompatibility, protection against oxidation, and microbiological failures [98,192].

Biodegradable films/coatings are made with biopolymers, such lipids, proteins, polysaccharides, used alone, or in combination. Among these, superior films (good gas barrier and mechanical properties) were obtained with proteins. A single natural polymer produces films with various good characteristics but poor aspects quality. Improvements can be achieved when combining two or more polymers from different origins [8].

\subsubsection{Sunflower Oil Cake (SuOC)}

Suput et al. [98] investigated the possibility to use SuOC for the production of biopolymer films and the effects of $\mathrm{pH}$ and temperature on them. The final products were firm, smooth, flexible, dark brownish-green, shiny, with a sunflower flagrance; with the increase in temperature and $\mathrm{pH}$ tensile strength increased; water vapor permeability, swelling, and solubility were uniform but decreased at high temperatures. Optimal films were obtained at $\mathrm{pH} 12$ and $90{ }^{\circ} \mathrm{C}$. Addition of $0.25-1 \%$ parsley and rosemary essential oils decreased tensile strength and increased elongation at break and the antioxidant activity. Water permeability increased with rosemary and decreased parsley [193].

Films prepared with protein isolates and concentrates from SuOC have good barrier properties, high adhesive characteristics, high water solubility oil, and organic solvents resistance [192]. Comparing them films prepared with soy protein isolates and different amounts of phenolic compounds, they have low elongation, deformation, and elasticity, but higher antioxidant capacity $[194,195]$.

\subsubsection{Pumpkin Oil Cake (PuOC)}

Cakes resulted from cold pressing of pumpkin seeds are a source of natural macromolecules with film-forming ability. By substituting gelatin with an increasing percentage of pumpkin oilcake, Popovic, et al. [196] created films with adequate characteristics. The best tensile strength was observed with a $40 \%$ addition. Solubility, antioxidant activity, and swelling capacity did not change when PuOC was added, but elongation at break increased by $20 \%$ at $95 \%$ addition. Subsequent studies investigated the possibility of using only pumpkin oilcake in film-forming and the possible impact of temperature and $\mathrm{pH}$ on them. Films with the highest antioxidant activity were obtained at $\mathrm{pH} 10$ and $60^{\circ} \mathrm{C}$. At $90^{\circ} \mathrm{C}$ and $\mathrm{pH} 12$ were created films with the highest tensile strength, elongation at break, and lowest gas 
permeability. Films produced at the same $\mathrm{pH}$ and temperature $50{ }^{\circ} \mathrm{C}$ have total soluble protein and matter content very high. When films are prepared at high temperature $\left(90^{\circ} \mathrm{C}\right)$ the surface is compact with nanoholes. At low temperature $\left(50^{\circ} \mathrm{C}\right)$ the holes are elder and this explains the low gas barrier ability [197].

Films obtained with pumpkin cake are not heat-sealable, so they were laminated with zein. Bulut et al. [198] analyzed the changes in barrier, mechanical and physicochemical properties in bilayer films made with pumpkin oil cakes and zein and their pouches during four weeks of storage. During this time, the film loses in moisture, total soluble matter, and swelling ability. It was observed also a good barrier for oxygen but moderate for carbon dioxide. The pouches present a high percentage of oxygen and low in dioxide carbon due to the decrease in heat deal strength and gas transmission rate. The addition of stabilizers as 30\% glycerol and $0.5 \%$ xanthan, produced films with good mechanical properties, poor barrier for water vapor, and very good to oxygen. With the increase in concentrations, the transmission rate of dioxide carbon also increased. This can be advantageous for maintaining the quality and shelf-life of foods such as cheese, vegetables, and fruits [199].

The incorporation of different essential oils (caraway, wintery savory, and basil essential oils) in the biopolymer matrix (chitosan, Tween 20) increased the edible packaging antimicrobial and antioxidant activity. Chitosan films with caraway are elastic, oil resistance, present low permeability to gases, effective against Escherichia coli and Staphylococcus aureus, but only with the lowest amount of caraway the antioxidant activity increases [194]. When increasing the concentration of Tween 20 in films with winter savory the antioxidant activity also increases, reverse was observed in films with basil $[98,200]$.

The ability of protein isolates to create biopolymer films with different amounts of plasticizer and $\mathrm{pH}$ values was analyzed. At $\mathrm{pH} 4-8$, they could not be synthesized and only moderate amount of plasticizer produce suitable final products. Besides this, they present excellent oxygen, nitrogen, dioxide carbon, and gas barrier properties (150-250 better than plastic) [201].

\subsubsection{Soybean Oil Cake}

In comparison to other plant protein sources, soy proteins are superior materials for the production of films, they are much cleaner, smoother, and flexible. Their adhesive ability is characterized by low water resistance and gluing strength [8]. However, during long time storage, they suffer aging (aggregation, thiol oxidation, molecular rearrangement, and spontaneous relaxation). Improvement of their properties can be done by: application of cellulose and starch, enzyme-mediated and chemical crosslinking (with rutin, epicatechin, genipin, metal methacrylate, and dialdehyde carboxymethyl cellulose). Moreover, the film's submission to high temperature and/or pressure can increase their tensile strength and decrease their permeability and water sensitivity [192].

\subsubsection{Rapeseed Oil Cake}

The formation of films only with rapeseed protein cannot be done, because they present bad mechanical properties and no antimicrobial activity, thus plasticizer and emulsifier can be used. For example, gelatin and agarose increase tensile strength, and decrease elongation at break [98]. The use of protein hydrolysate with chitosan gives anti-microbial films with high activity against Staphylococcus aureus, Bacillus subtilis, and Escherichia coli [127].

\subsubsection{Peanut Oil Cake}

The utilization of only peanut protein isolate form brittle films, glycerol was found to be the most suitable plasticizer, producing optimal mechanical properties without influencing the barrier properties. Moreover, at high $\mathrm{pH}$ and temperature, they have good appearance and color, low water sensitivity, and, vapor, oxygen permeability [98].

Improvement of the characteristics can be realized, also with crosslinking with citric acid and a mixture of pea starch. The first one led to the improvement of tensile strength and a decrease in 
elongation at break, and water permeability. The second one improves coloration and elongation at break, and decrease tensile strength, water permeability, and total soluble matter [202,203].

Films have antimicrobial properties when are activated with different proportion of thymol. The latter, inhibit l. plantarum, E. Coli, S. aureus, and P. aeruginosa, at minimum concentration [127].

Comparing to the protein-based films, those create with defatted peanut flour create films, that are more transparent and excellent water barrier [204].

Edible fiber films are difficult to make because they have poor film-forming properties. To improve this, Wan [205] performed a dynamic high-pressure micro-fluidization treatment. The final films have excellent solubility and mechanical properties and can be used for packaging noodles, spices, biscuits, and candies.

\subsection{Landfill and Bio-Fuel Production}

The most common and cheap waste valorization is landfilling, defined as the embankment, compression, and disposal in appropriate sites. The decomposition of residues leads to methane production from heavy metals and organic compounds [206].

Due to the high content in an organic compound, energy can be obtained from food wastes/residues. There are two methods for biofuel conversion: thermochemical, more suitable for residues with low moisture and anaerobic digestion, for residues with high organic and water content. The first one converts biomass rich in energy into intermediate products (liquid or gaseous) and includes pyrolysis, combustion, and gasification. Incineration is another viable option but involves high cost, and negative environmental impact [4].

Economics of the bio-diesel production improved by using residual seedcakes as the main co-product. Because of their toxic compounds some oilcakes are unusable for consumption but have a potential energy production. The high protein content of oilseed cakes can cause some disadvantages on the pyrolysis process (decrease of the rate of degradation) [206].

\section{Challenges and Future Perspectives}

Oilseed by-products are an important source of dietary fiber, proteins and compounds with antioxidants properties. Further studies, need to be done on the extraction, utilization, and incorporation of dietary fiber and antioxidants in food products.

The researches accomplished until now highlights the possibility of adding appropriate amounts of by-products from oil-industry as functional ingredients in bakery, and dairy products without influencing negatively the quality of the final products. More investigations are required at the molecular structure. Additionally, there are limited studies about the rheological properties of dough with different oilcakes levels and particle sizes.

\section{Conclusions}

This review highlights the potential application of the ample amounts of wastes and by-products generated during the supply chain, primarily used as energy sources, landfills, and animal feedstuffs. Moreover, we have described new green methods for their recycling and further reuse in various food and pharmaceutical industries. This green approach also allows the protection of both the environment and people.

Oil cake/meal are the by-products obtained after the extraction of oil from seeds. It can be used in both animal and human diet because contain high amounts of bioactive compounds that can be isolated and used in foods. These residues can also act as a substrate in the production of low-cost value-added products such as fuel, surfactants, enzymes, antibiotics, vitamins, natural pigments, flavors components, and health promoting components, such as dietary fibers, amino acids, flavonoids, phytochemicals and proteins. All bioactive components recovered from residues can be used as essential ingredients to produce functional ingredient, achieving thus effective waste utilization and the successful realization of the zero waste and circular economy concepts 
Waste valorization, in the perception of the circular economy, represents a challenge but at the same time could allow the reuse of materials into the supply chain as they add more value to foods, reduce costs, allow economic growth and reduce risks caused by their disposal in the environment.

Author Contributions: P.A. and A.S. contributed equally to the collection of data and preparation of the paper. All authors have read and agreed to the published version of the manuscript

Funding: This work was supported by a grant of Romanian Ministry of Education and Research, CCCDI-UEFISCDI, project number PN-III-P2-2.1-PED-2019-3863, within PNCDI III

Conflicts of Interest: The authors declare no conflict of interest

\section{References}

1. Borrello, M.; Caracciolo, F.; Lombardi, A.; Pascucci, S.; Cembalo, L. Consumers' Perspective on Circular Economy Strategy for Reducing Food Waste. Sustainability 2017, 9, 141. [CrossRef]

2. Pesce, M.; Tamai, I.; Guo, D.; Critto, A.; Brombal, D.; Wang, X.; Cheng, H.; Marcomini, A. Circular Economy in China: Translating Principles into Practice. Sustainability 2020, 12, 832. [CrossRef]

3. Esposito, B.; Sessa, M.R.; Sica, D.; Malandrino, O. Towards Circular Economy in the Agri-Food Sector. A Systematic Literature Review. Sustainability 2020, 12, 7401. [CrossRef]

4. Otles, S.; Despoudi, S.; Bucatariu, C.; Kartal, C. Food waste management, valorization, and sustainability in the food industry. In Food Waste Recovery, 1st ed.; Galanakis, C.M., Ed.; Elsevier Inc.: London, UK, 2015; pp. 3-23.

5. Mateos-Aparicio, I.; Matias, A. Food industry processing by-products in foods. In The Role of Alternative and Innovative Food Ingredients and Products in Consumer Wellness, 1st ed.; Galanakis, C., Ed.; Elsevier Inc.: London, UK, 2019; pp. 239-281.

6. Kumar, S.; Kushwaha, R.; Verma, M.L. Recovery and utilization of bioactives from food processing waste. In Biotechnological Production of Bioactive Compounds, 1st ed.; Verma, M.L., Chandel, A.K., Eds.; Elsevier: Amsterdam, The Netherlands, 2020; pp. 37-68.

7. García-Rebollar, P.; Cámara, L.; Lázaro, R.; Dapoza, C.; Pérez-Maldonado, R.; Mateos, G. Influence of the origin of the beans on the chemical composition and nutritive value of commercial soybean meals. Anim. Feed. Sci. Technol. 2016, 221, 245-261. [CrossRef]

8. Arrutia, F.; Binner, E.; Williams, P.; Waldron, K.W. Oilseeds beyond oil: Press cakes and meals supplying global protein requirements. Trends Food Sci. Technol. 2020, 100, 88-102. [CrossRef]

9. Wanasundara, J.; Tan, S.; Alashi, A.; Pudel, F.; Blanchard, C.L. Proteins from Canola/Rapeseed: Current Status. In Sustainable Protein Sources; Nadathur, S.R., Wanasundara, J.P.D., Scalin, L., Eds.; Elsevier Inc.: London Wall, UK, 2017; pp. 285-304.

10. Lomascolo, A.; Uzan-Boukhris, E.; Sigoillot, J.-C.; Fine, F. Rapeseed and sunflower meal: A review on biotechnology status and challenges. Appl. Microbiol. Biotechnol. 2012, 95, 1105-1114. [CrossRef]

11. Ranganayaki, S.; Vidhya, R.; Jaganmohan, R. Isolation and proximate determination of protein using defatted sesame seed oil cake. Int. J. Nutr. Metab. 2012, 4, 141-145.

12. Krimer-Malešević, V. Pumpkin Seeds: Phenolic Acids in Pumpkin Seed (Curcubita pepo L.). In Nuts and Seeds in Health and Disease Prevention, 2nd ed.; Preedy, V., Watson, R., Eds.; Elsevier Inc.: London, UK, 2020; pp. 533-542.

13. Özbek, Z.A.; Ergönül, P.G. Cold pressed pumpkin seed oil. In Cold Pressed Oils, 1st ed.; Ramadan, F.M., Ed.; Elsevier Inc.: London, UK, 2020; pp. 219-229.

14. Apostol, L.; Berca, L.; Mosoiu, C.; Badea, M.; Bungau, S.; Oprea, O.B.; Cioca, G. Partially Defatted Pumpkin (Cucurbita maxima) Seeds-A Rich Source of Nutrients for Use in Food Products. Rev. Chim. 2018, 69, 1398-1402. [CrossRef]

15. Eyres, L.; Eyres, M. Flaxseed (linseed) fibre-nutritional and culinary uses-A review. Food N. Z. 2014, 14, 26.

16. Mullen, A.M.; Alvarez, C.; Pojić, M.; Hadnadev, T.D.; Papageorgiou, M. Classification and target compounds. In Food Waste Recovery: Processing Technologies and Industrial Techniques, 1st ed.; Galanakis, C., Ed.; Elsevier Inc.: London, UK, 2015; pp. 25-57.

17. Sarwar, F.; Qadri, N.A.; Moghal, S. The role of oilseeds nutrition in human health: A critical review. J. Cereals Oilseeds 2013, 4, 97-100. [CrossRef] 
18. Savoire, R.; Lanoisellé, J.-L.; Vorobiev, E. Mechanical Continuous Oil Expression from Oilseeds: A Review. Food Bioprocess Technol. 2012, 6, 1-16. [CrossRef]

19. Ramadan, M.F. Introduction to cold pressed oils: Green technology, bioactive compounds, functionality, and applications. In Cold Pressed Oils, 1st ed.; Ramadan, F.M., Ed.; Elsevier Inc.: London, UK, 2020; pp. 1-5.

20. Leming, R.; Lember, A. Chemical composition of expeller-extracted and cold-pressed rapeseed cake. Agraarteadu 2005, 16, 103-109.

21. Sunil, L.; Appaiah, P.; Kumar, P.K.P.; Krishna, A.G.G. Preparation of food supplements from oilseed cakes. J. Food Sci. Technol. 2014, 52, 2998-3005. [CrossRef] [PubMed]

22. Gupta, A.; Sharma, R.; Sharma, S.; Singh, B. Oilseed as potential functional food Ingredient. In Trends $\mathcal{E}$ Prospects in Food Technology, Processing and Preservation, 1st ed.; Prodyut Kumar, P., Mahawar, M.K., Abobatta, W., Panja, P., Eds.; Today and Tomorrow's Printers and Publishers: New Delhi, India, 2018; pp. 25-58.

23. Östbring, K.; Malmqvist, E.; Nilsson, K.; Rosenlind, I.; Rayner, M. The Effects of Oil Extraction Methods on Recovery Yield and Emulsifying Properties of Proteins from Rapeseed Meal and Press Cake. Foods 2019, 9, 19. [CrossRef] [PubMed]

24. Bochkarev, M.S.; Egorova, E.Y.; Reznichenko, I.Y.; Poznyakovskiy, V.M. Reasons for the ways of using oilcakes in food industry. Foods Raw Mater. 2016, 4, 4-12. [CrossRef]

25. Tarek-Tilistyák, J.; Juhász-Román, M.; Jeko, J.; Mathe, E. Short-term storability of oil seed and walnut cake-Microbiological aspect. Acta Aliment. 2014, 43, 632-639. [CrossRef]

26. Mannucci, A.; Castagna, A.; Santin, M.; Serra, A.; Mele, M.; Ranieri, A. Quality of flaxseed oil cake under different storage conditions. LWT 2019, 104, 84-90. [CrossRef]

27. Marchetti, L.; Romero, L.; Andrés, S.C.; Califano, A. Characterization of pecan nut expeller cake and effect of storage on its microbiological and oxidative quality. Grasas Aceites 2018, 68, 226. [CrossRef]

28. Volli, V.; Singh, R. Production of bio-oil from de-oiled cakes by thermal pyrolysis. Fuel 2012, 96, 579-585. [CrossRef]

29. Rezvani, M.; Kluth, H.; Bulang, M.; Rodehutscord, M. Variation in amino acid digestibility of rapeseed meal studied in caecectomised laying hens and relationship with chemical constituents. Br. Poult. Sci. 2012, 53, 665-674. [CrossRef]

30. Thanaseelaan, V. Proximate Analysis, Mineral and Amino Acid Profiles of Deoiled Rapeseed Meal. Int. J. Food Agric. Vet. Sci. 2013, 3, 66-69.

31. Sari, Y.W.; Bruins, M.E.; Sanders, J.P. Enzyme assisted protein extraction from rapeseed, soybean, and microalgae meals. Ind. Crop. Prod. 2013, 43, 78-83. [CrossRef]

32. Maison, T. Evaluation of the Nutritional Value of Canola Meal, 00-Rapeseed Meal, and 00-Rapeseed Expellers Fed To Pigs. Ph.D. Thesis, University of Illinois at Urbana-Champaign, Urbana-Champaign, IL, USA, 2013.

33. Thiel, A.; Muffler, K.; Tippkötter, N.; Suck, K.; Sohling, U.; Hruschka, S.M.; Ulber, R. A novel integrated downstream processing approach to recover sinapic acid, phytic acid and proteins from rapeseed meal. J. Chem. Technol. Biotechnol. 2015, 90, 1999-2006. [CrossRef]

34. Egorova, T.A.; Lenkova, T.H. Rapseed (Brassica napus L.) and its prospective useage (review). Agric. Biol. 2015, 50, 172-182.

35. Choi, H.B.; Jeong, J.H.; Kim, D.H.; Lee, Y.; Kwon, H.; Kim, Y.Y. Influence of Rapeseed Meal on Growth Performance, Blood Profiles, Nutrient Digestibility and Economic Benefit of Growing-finishing Pigs. Asian-Australasian J. Anim. Sci. 2015, 28, 1345-1353. [CrossRef] [PubMed]

36. Tofanica, B.M. Rapeseed-A Valuable Renewable Bioresource. Cellul. Chem. Technol. 2019, 53, 837-849. [CrossRef]

37. Amores, G.; Virto, M.; Nájera, A.I.; Mandaluniz, N.; Arranz, J.; Bustamante, M.Á.; Valdivielso, I.; De Gordoa, J.R.; Garcia-Rodriguez, A.; Barron, L.J.; et al. Rapeseed and sunflower oilcake as supplements for dairy sheep: Animal performance and milk fatty acid concentrations. J. Dairy Res. 2014, 81,410-416. [CrossRef]

38. Jabłoński, S.J.; Biernacki, P.; Steinigeweg, S.; Łukaszewicz, M. Continuous mesophilic anaerobic digestion of manure and rape oilcake-Experimental and modelling study. Waste Manag. 2015, 35, 105-110. [CrossRef]

39. Shi, C.; He, J.; Yu, J.; Yu, B.; Huang, Z.; Mao, X.; Zheng, P.; Chen, D. Solid state fermentation of rapeseed cake with Aspergillus niger for degrading glucosinolates and upgrading nutritional value. J. Anim. Sci. Biotechnol. 2015, 6, 1-7. [CrossRef]

40. Kaczmarek, P.; Korniewicz, D.; Lipinski, K.; Mazur, M. Chemical composition of rapeseed products and their use in pig nutrition. Pol. J. Nat. Sci. 2016, 31, 545-562. 
41. Salazar-Villanea, S.; Bruininx, E.M.; Gruppen, H.; Hendriks, W.H.; Carré, P.; Quinsac, A.; Van Der Poel, A.F. Physical and chemical changes of rapeseed meal proteins during toasting and their effects on in vitro digestibility. J. Anim. Sci. Biotechnol. 2016, 7, 1-11. [CrossRef] [PubMed]

42. Mosenthin, R.; Messerschmidt, U.; Sauer, N.; Carré, P.; Quinsac, A.; Schöne, F. Effect of the desolventizing/toasting process on chemical composition and protein quality of rapeseed meal. J. Anim. Sci. Biotechnol. 2016, 7, 36. [CrossRef]

43. Rommi, K.; Hakala, T.K.; Holopainen, U.; Nordlund, E.; Poutanen, K.; Lantto, R. Effect of Enzyme-Aided Cell Wall Disintegration on Protein Extractability from Intact and Dehulled Rapeseed (Brassica rapaL. andBrassica napusL.) Press Cakes. J. Agric. Food Chem. 2014, 62, 7989-7997. [CrossRef]

44. Tyapkova, O.; Osen, R.; Wagenstaller, M.; Baier, B.; Specht, F.; Zacherl, C. Replacing fishmeal with oilseed cakes in fish feed-A study on the influence of processing parameters on the extrusion behavior and quality properties of the feed pellets. J. Food Eng. 2016, 191, 28-36. [CrossRef]

45. Nega, T. Review on Nutritional Limitations and Opportunities of using Rapeseed Meal and other Rape Seed by-Products in Animal Feeding. J. Nutr. Health Food Eng. 2018, 8, 1. [CrossRef]

46. Martin, A.; Osen, R.; Greiling, A.; Karbstein, H.P.; Emin, A. Effect of rapeseed press cake and peel on the extruder response and physical pellet quality in extruded fish feed. Aquaculture 2019, 512, 734316. [CrossRef]

47. Cozea, A.; Ionescu, N.; Popescu, M.; Neagu, M.; Gruia, R. Comparative study concerning the composition of certain oil cakes with phytotherapeutical potential. Rev. Chim. 2016, 67, 422-425.

48. Halmemies-Beauchet-Filleau, A.; Rinne, M.; Lamminen, M.; Mapato, C.; Ampapon, T.; Wanapat, M.; Vanhatalo, A. Alternative and novel feeds for ruminants: Nutritive value, product quality and environmental aspects. Animal 2018, 12, s295-s309. [CrossRef]

49. Fetzer, A.; Herfellner, T.; Stäbler, A.; Menner, M.; Eisner, P. Influence of process conditions during aqueous protein extraction upon yield from pre-pressed and cold-pressed rapeseed press cake. Ind. Crop. Prod. 2018, 112, 236-246. [CrossRef]

50. Oliveira, F.; Souza, C.E.; Peclat, V.R.; Salgado, J.M.; Ribeiro, B.D.; Coelho, M.A.; Venâncio, A.; Belo, I. Optimization of lipase production by Aspergillus ibericus from oil cakes and its application in esterification reactions. Food Bioprod. Process. 2017, 102, 268-277. [CrossRef]

51. Tan, S.H.; Mailer, R.J.; Blanchard, C.L.; Agboola, S.O. Extraction and characterization of protein fractions from Australian canola meals. Food Res. Int. 2011, 44, 1075-1082. [CrossRef]

52. Sadh, P.K.; Duhan, S.; Duhan, J.S. Agro-industrial wastes and their utilization using solid state fermentation: A review. Bioresour. Bioprocess. 2018, 5, 1. [CrossRef]

53. Teh, S.S.; Bekhit, A.E.; Carne, A.; Birch, J. Effect of the defatting process, acid and alkali extraction on the physicochemical and functional properties of hemp, flax and canola seed cake protein isolates. J. Food Meas. Charact. 2013, 8, 92-104. [CrossRef]

54. Capitani, M.; Spotorno, V.; Nolasco, S.; Tomás, M. Physicochemical and functional characterization of by-products from chia (Salvia hispanica L.) seeds of Argentina. LWT 2012, 45, 94-102. [CrossRef]

55. Montrimaitè, K.; Moščenkova, E. Food Science and Applied Biotechnology. Food Sci. Appl. Biotechnol. 2018, 1, 154-164. [CrossRef]

56. Kenari, R.E.; Mohsenzadeh, F.; Amiri, Z.R. Antioxidant activity and total phenolic compounds of Dezful sesame cake extracts obtained by classical and ultrasound-assisted extraction methods. Food Sci. Nutr. 2014, 2, 426-435. [CrossRef]

57. Nadeem, M.; Situ, C.; Mahmud, A.; Khalique, A.; Imran, M.; Rahman, F.; Khan, S. Antioxidant Activity of Sesame (Sesamum indicum L.) Cake Extract for the Stabilization of Olein Based Butter. J. Am. Oil Chem. Soc. 2014, 91, 967-977. [CrossRef]

58. Yasothai, R. Chemical composition of sesame oil cake-Rieview. Int. J. Sci. Environ. Technol. 2014, 3, 827-835.

59. Grasso, S. Extruded snacks from industrial by-products: A review. Trends Food Sci. Technol. 2020, 99, 284-294. [CrossRef]

60. Benítez, R.B.; Bonilla, R.A.O.; Franco, J.M. Comparison of two sesame oil extraction methods: Percolation and pressed. Biotecnoloía Sect. Agropecu. Agroind. 2016, 14, 10. [CrossRef]

61. Mohdaly, A.A.; Smetanska, I.; Ramadan, M.F.; Sarhan, M.A.; Mahmoud, A.; Ramadan, M.F. Antioxidant potential of sesame (Sesamum indicum) cake extract in stabilization of sunflower and soybean oils. Ind. Crop. Prod. 2011, 34, 952-959. [CrossRef] 
62. Carvalho, C.W.; Takeiti, C.Y.; Freitas, D.D.; Ascheri, J.L. Use of sesame oil cake (Sesamum indicum L.) on corn expanded extrudates. Food Res. Int. 2012, 45, 434-443. [CrossRef]

63. Uppuluri, K.B.; Dasari, R.K.; Sajja, V.; Jacob, A.S.; Reddy, D.S. Optimization of 1-Asparaginase Production by Isolated Aspergillus niger C4 from Sesame (black) Oil Cake under SSF using Box-Behnken Design in Column Bioreactor. Int. J. Chem. React. Eng. 2013, 11, 103-109. [CrossRef]

64. Saleh, M.; Ghazzawi, H.; Al-Ismail, K.; Akash, M.; Al-Dabbas, M. Sesame-oil-cake (SOC) impacted consumer liking of a traditional Jordanian dessert; a mixture response surface model approach. Int. Food Res. J. 2016, 23, 2096-2102.

65. Capellini, M.C.; Chiavoloni, L.; Giacomini, V.; Rodrigues, C.E. Alcoholic extraction of sesame seed cake oil: Influence of the process conditions on the physicochemical characteristics of the oil and defatted meal proteins. J. Food Eng. 2019, 240, 145-152. [CrossRef]

66. Nagendra Prasad, M.N.; Sanjay, K.R.; Prasad, D.S.; Vijay, N.; Kothari, R.; Nanjunda Swamy, S. A Review on Nutritional and Nutraceutical Properties of Sesame. J. Nutr. Food Sci. 2012, 2, 1-6. [CrossRef]

67. Das, P.; Ghosh, K. Improvement of nutritive value of sesame oil cake in formulated diets for rohu, Labeo rohita (Hamilton) after bio-processing through solid state fermentation by a phytase-producing fish gut bacterium. Int. J. Aquat. Biol. 2015, 3, 89-101.

68. Elsorady, M.E. Characterization and functional properties of proteins isolated from flaxseed cake and sesame cake. Croat. J. Food Sci. Technol. 2020, 12, 77-83. [CrossRef]

69. Hejazi, A.; Omar, J.M.A. Effect of Feeding Sesame Oil Cake on Performance, Milk and Cheese Quality of Anglo-Nubian Goats. Hebron Univ. Res. J. 2009, 4, 81-91.

70. Omer, H.A.A.; Ahmed, S.M.; Abdel-Magid, S.S.; Bakry, B.A.; El-Karamany, M.F.; El-Sabaawy, E.H. Nutritional impact of partial or complete replacement of soybean meal by sesame (Sesamum indicum) meal in lambs rations. Bull. Natl. Res. Cent. 2019, 43, 98. [CrossRef]

71. Prakash, K.; Naik, S.; Vadivel, D.; Hariprasad, P.; Gandhi, D.; SaravanaDevi, S. Utilization of defatted sesame cake in enhancing the nutritional and functional characteristics of biscuits. J. Food Process. Preserv. 2018, 42, e13751. [CrossRef]

72. Bigoniya, P.; Nishad, R.; Singh, C.S. Preventive effect of sesame seed cake on hyperglycemia and obesity against high fructose-diet induced Type 2 diabetes in rats. Food Chem. 2012, 133, 1355-1361. [CrossRef]

73. Shu, Z.; Liu, L.; Geng, P.; Liu, J.; Shen, W.; Tu, M. Sesame cake hydrolysates improved spatial learning and memory of mice. Food Biosci. 2019, 31, 100440. [CrossRef]

74. Reshma, M.; Namitha, L.; Sundaresan, A.; Kiran, C.R. Total Phenol Content, Antioxidant Activities and $\alpha$-Glucosidase Inhibition of Sesame Cake Extracts. J. Food Biochem. 2012, 37, 723-731. [CrossRef]

75. Achouri, A.; Nail, V.; Boye, J.I. Sesame protein isolate: Fractionation, secondary structure and functional properties. Food Res. Int. 2012, 46, 360-369. [CrossRef]

76. Zheng, Y.; Li, Y. Physicochemical and functional properties of coconut (Cocos nucifera L) cake dietary fibres: Effects of cellulase hydrolysis, acid treatment and particle size distribution. Food Chem. 2018, 257, 135-142. [CrossRef] [PubMed]

77. Paweł, S.; Kazimierz, Z.; Starek, A.; Żukiewicz-Sobczak, W.; Sagan, A.; Zdybel, B.; Andrejko, D. Compaction Process as a Concept of Press-Cake Production from Organic Waste. Sustainability 2020, 12, 1567. [CrossRef]

78. Te, K.G.; Go, A.W.; Wang, H.J.; Guevarra, R.G.; Cabatingan, L.K.; Tabañag, I.D.; Angkawijaya, A.E.; Ju, Y.-H. Extraction of lipids from post-hydrolysis copra cake with hexane as solvent: Kinetic and equilibrium data. Renew. Energy 2020, 158, 311-323. [CrossRef]

79. Akhter, P.; Mishra, A.; Mishra, V.; Raghav, A. Alpha amylase production from Aspergillus terreus UF39 using oil cakes. Eurpean J. Biotechnol. Bioci. 2017, 5, 15-21.

80. Contreras, M.D.M.; Romero, I.; Moya, M.; Castro, E. Olive-derived biomass as a renewable source of value-added products. Process Biochem. 2020, 97, 43-56. [CrossRef]

81. Moftah, O.A.S.; Grbavcic, S.; Zuza, M.; Luković, N.; Bezbradica, D.; Knežević-Jugović, Z.D. Adding Value to the Oil Cake as a Waste from Oil Processing Industry: Production of Lipase and Protease by Candida utilis in Solid State Fermentation. Appl. Biochem. Biotechnol. 2011, 166, 348-364. [CrossRef]

82. Ramachandran, S.; Singh, S.K.; Larroche, C.; Soccol, C.R.; Pandey, A. Oil cakes and their biotechnological applications-A review. Bioresour. Technol. 2007, 98, 2000-2009. [CrossRef] [PubMed] 
83. Bakkalbaşi, E.; Meral, R.; Dogan, I.S. Bioactive Compounds, Physical and Sensory Properties of Cake Made with Walnut Press-Cake. J. Food Qual. 2015, 38, 422-430. [CrossRef]

84. Grosu, C.; Boaghi, E.; Paladi, D.; Deseatnicova, O.; Vladislav, R. Prosects of using walnut oil cake in food industry. In Proceedings of the International Conference Modern Technologies in the Food Industry, Chișinău, Moldova, 1-3 November 2012; pp. 362-365.

85. Jokić, S.; Moslavac, T.; Bošnjak, A.; Aladić, K.; Rajić, M.; Bilić, M. Optimization of walnut oil production. Croat. J. Food Sci. Technol. 2014, 6, 27-35.

86. Mir, M.A.; Sharma, R.K.; Rastogi, A.; Barman, K. Effect of incorporation of walnut cake (Juglans regia) in concentrate mixture on degradation of dry matter, organic matter and production of microbial biomass in vitro in goat. Veter-World 2015, 8, 1172-1176. [CrossRef]

87. Bardeau, T.; Savoire, R.; Cansell, M.; Subra-Paternault, P. Recovery of oils from press cakes by $\mathrm{CO}_{2}$-based technology. OCL 2015, 22, D403. [CrossRef]

88. Pop, A.; Paucean, A.; Socaci, S.A.; Alexa, E.; Man, S.M.; Muresan, V.; Chis, M.S.; Salanta, L.; Popescu, I.; Berbecea, A.; et al. Quality characteristics and volatile profile of macarons modified withwalnut oilcake by-product. Molecules 2020, 25, 2214. [CrossRef]

89. Wang, R.; Shaarani, S.M.; Casas-Godoy, L.; Melikoğlu, M.; Vergara, C.S.; Koutinas, A.; Webb, C. Bioconversion of rapeseed meal for the production of a generic microbial feedstock. Enzym. Microb. Technol. 2010, 47, 77-83. [CrossRef]

90. Jannathulla, R.; Dayal, J.S.; Ambasankar, K.; Muralidhar, M. Effect of Aspergillus niger fermented soybean meal and sunflower oil cake on growth, carcass composition and haemolymph indices in Penaeus vannamei Boone, 1931. Aquaculture 2018, 486, 1-8. [CrossRef]

91. Zamindar, N.; Bashash, M.; Khorshidi, F.; Serjouie, A.; Shirvani, M.A.; Abbasi, H.; Sedaghatdoost, A. Antioxidant efficacy of soybean cake extracts in soy oil protection. J. Food Sci. Technol. 2017, 54, 2077-2084. [CrossRef] [PubMed]

92. Gerliani, N.; Hammami, R.; Aïder, M. A comparative study of the functional properties and antioxidant activity of soybean meal extracts obtained by conventional extraction and electro-activated solutions. Food Chem. 2020, 307, 125547. [CrossRef]

93. Jahan, D.; Hussain, L.; Islam, M.; Khan, M. Comparative Study of Mustard Oil Cake and Soybean Meal Based Artificial Diet for Rohu, Labeo rohita (Ham.) Fingerlings. Agriculturists 2013, 11, 61-66. [CrossRef]

94. Tangendjaja, B. Quality control of feed ingredients for aquaculture. In Feed and Feeding Practices in Aquaculture, 1st ed.; Davis, D.A., Ed.; Woodhead Publishing: Cambridge, UK, 2015; pp. 141-169.

95. Jadhav, M.; Kagalkar, A.; Jadhav, S.; Govindwar, S.P.; Chakankar, M. Isolation, characterization, and antifungal application of a biosurfactant produced by Enterobacter sp. MS16. Eur. J. Lipid Sci. Technol. 2011, 113, 1347-1356. [CrossRef]

96. Grosu, C. Valorificarea Șrotului de nuci și Obținerea Produselor de Cofetărie. Ph.D. Thesis, Technical University of Moldova, Chişinău, Moldova, 2016.

97. Bhise, S.; Kaur, A.; Manikantan, M.; Singh, B. Development of textured defatted sunflower meal by extrusion using response surface methodology. Acta Aliment. 2015, 44, 251-258. [CrossRef]

98. Šuput, D.; Lazić, V.; Mađarev-Popović, S.; Hromiš, N.; Bulut, S.; Pezo, L.; Banićević, J. Effect of process parameters on biopolymer films based on sunflower oil cake. J. Process. Energy Agric. 2018, 22, 125-128. [CrossRef]

99. Serrapica, F.; Masucci, F.; Raffrenato, E.; Sannino, M.; Vastolo, A.; Barone, C.M.A.; Di Francia, A. High Fiber Cakes from Mediterranean Multipurpose Oilseeds as Protein Sources for Ruminants. Animal 2019, 9, 918. [CrossRef] [PubMed]

100. Lazaro, E.; Benjamin, Y.; Robert, M. The Effects of Dehulling on Physicochemical Properties of Seed Oil and Cake Quality of Sunflower. Tanzan. J. Agric. Sci. 2014, 13, 41-47.

101. Salgado, P.R.; Ortiz, S.E.M.; Petruccelli, S.; Mauri, A.N. Sunflower Protein Concentrates and Isolates Prepared from Oil Cakes Have High Water Solubility and Antioxidant Capacity. J. Am. Oil Chem. Soc. 2010, 88, 351-360. [CrossRef]

102. Budžaki, S.; Strelec, I.; Krnić, M.; Alilović, K.; Tišma, M.; Zelić, B. Proximate analysis of cold-press oil cakes after biological treatment with Trametes versicolor and Humicola grisea. Eng. Life Sci. 2018, 18, 924-931. [CrossRef]

103. Tirgar, M.; Silcock, P.; Carne, A.; Birch, E.J. Effect of extraction method on functional properties of flaxseed protein concentrates. Food Chem. 2017, 215, 417-424. [CrossRef] 
104. Stodolak, B.; Starzyńska-Janiszewska, A.; Bączkowicz, M. Aspergillus oryzae (Koji Mold) and Neurospora intermedia (Oncom Mold) application for flaxseed oil cake processing. LWT 2020, 131, 109651. [CrossRef]

105. Ganorkar, P.; Patel, J.M.; Shah, V.; Rangrej, V.V. Defatted flaxseed meal incorporated corn-rice flour blend based extruded product by response surface methodology. J. Food Sci. Technol. 2015, 53, 1867-1877. [CrossRef]

106. Radočaj, O.; Dimic, E.; Tsao, R. Effects of Hemp (Cannabis sativa L.) Seed Oil Press-Cake and Decaffeinated Green Tea Leaves (Camellia sinensis) on Functional Characteristics of Gluten-Free Crackers. J. Food Sci. 2014, 79, C318-C325. [CrossRef] [PubMed]

107. Panak Balentić, J.; Jozinović, A.; Ačkar, Đ.; Babić, J.; Miličević, B.; Benšić, M.; Jokić, S.; Šarić, A.; Šubarić, D. Nutritionally improved third generation snacks produced by supercritical CO 2 extrusion I. Physical and sensory properties. J. Food Process. Eng. 2018, 42, e12961. [CrossRef]

108. Jozinović, A.; AčkAr, Đ.; Jokić, S.; BABić, J.; BAlentić, J.P.; BAnožić, M.; ŠuBArić, D. Optimisation of extrusion variables for the production of corn snack products enriched with defatted hemp cake. Czech J. Food Sci. 2017, 35, 507-516. [CrossRef]

109. Bello, F.; Salami, I.; Sani, I.; Abdulhamid, A.; Musa, I. Evaluation of Some Antinutritional Factors in Oil-Free White Sesamum indicum L. Seed Cake. Int. J. Food Nutr. Saf. 2013, 4, 27-33.

110. Tan, S.H.; Mailer, R.J.; Blanchard, C.L.; Agboola, S.O. Canola Proteins for Human Consumption: Extraction, Profile, and Functional Properties. J. Food Sci. 2010, 76, R16-R28. [CrossRef] [PubMed]

111. Teh, S.S.; Bekhit, A.E. Utilization of Oilseed Cakes for Human Nutrition and Health Benefits. In Agricultural Biomass Based Potential Materials; Hakeem, K.R., Jawaid, M., Alothman, O.Y., Eds.; Springer International Publishing: Cham, Switzerland, 2015; pp. 191-229.

112. Dong, F.M.; Hardy, R.W.; Higgs, D.A. Antinutritional factors. In The Encyclopedia of Aquaculture; Stickney, R.R., Ed.; John Wiley and Sons: New York, NY, USA, 2000; pp. 45-51.

113. Pojić, M.; Hadnađev, T.R.D.; Hadnađev, M.; Rakita, S.; Brlek, T. Bread Supplementation with Hemp Seed Cake: A By-Product of Hemp Oil Processing. J. Food Qual. 2015, 38, 431-440. [CrossRef]

114. Łopusiewicz, Ł.; Drozłowska, E.; Siedlecka, P.; Mężyńska, M.; Bartkowiak, A.; Sienkiewicz, M.; Zielińska-Bliźniewska, H.; Kwiatkowski, P. Development, Characterization, and Bioactivity of Non-Dairy Kefir-Like Fermented Beverage Based on Flaxseed Oil Cake. Foods 2019, 8, 544. [CrossRef]

115. Ghosh, K.; Mandal, S. Nutritional evaluation of groundnut oil cake in formulated diets for rohu, Labeo rohita (Hamilton) fingerlings after solid state fermentation with a tannase producing yeast, Pichia kudriavzevii (GU939629) isolated from fish gut. Aquac. Rep. 2015, 2, 82-90. [CrossRef]

116. Duliński, R.; Stodolak, B.; Byczyński, Ł.; Poreda, A.; Starzyńska-Janiszewska, A.; Żyła, K. Solid-State Fermentation Reduces Phytic Acid Level, Improves the Profile of Myo-Inositol Phosphates and Enhances the Availability of Selected Minerals in Flaxseed Oil Cake. Food Technol. Biotechnol. 2017, 55, 413-419. [CrossRef] [PubMed]

117. Fărcaş, A.C.; Socaci, S.A.; Diaconeasa, Z.M. Introductory Chapter: From Waste to New Resources. In Food Preservation and Waste Exploitation., 1st ed.; Socaci, S.A., Fărcas, A.C., Aussenac, T., Eds.; IntechOpen: London, UK, 2019; pp. 1-11.

118. Baiano, A. Recovery of Biomolecules from Food Wastes-A Review. Molecules 2014, 19, 14821-14842. [CrossRef] [PubMed]

119. Hussain, S.; Jõudu, I.; Bhat, R. Dietary Fiber from Underutilized Plant Resources-A Positive Approach for Valorization of Fruit and Vegetable Wastes. Sustainability 2020, 12, 5401. [CrossRef]

120. Fierascu, R.C.; Fierascu, I.; Avramescu, S.M.; Sieniawska, E. Recovery of Natural Antioxidants from Agro-Industrial Side Streams through Advanced Extraction Techniques. Molecules 2019, 24, 4212. [CrossRef] [PubMed]

121. Sá, A.G.A.; Moreno, Y.M.F.; Carciofi, B.A.M. Plant proteins as high-quality nutritional source for human diet. Trends Food Sci. Technol. 2020, 97, 170-184. [CrossRef]

122. Östbring, K.; Tullberg, C.; Burri, S.C.; Malmqvist, E.; Rayner, M. Protein Recovery from Rapeseed Press Cake: Varietal and Processing Condition Effects on Yield, Emulsifying Capacity and Antioxidant Activity of the Protein Rich Extract. Foods 2019, 8, 627. [CrossRef] [PubMed]

123. Kajla, P.; Sharma, A.; Sood, D.R. Flaxseed-A potential functional food source. J. Food Sci. Technol. 2014, 52, 1857-1871. [CrossRef] [PubMed]

124. Chatterjee, R.; Dey, T.K.; Ghosh, M.; Dhar, P. Enzymatic modification of sesame seed protein, sourced from waste resource for nutraceutical application. Food Bioprod. Process. 2015, 94, 70-81. [CrossRef] 
125. Aider, M.; Barbana, C. Canola proteins: Composition, extraction, functional properties, bioactivity, applications as a food ingredient and allergenicity-A practical and critical review. Trends Food Sci. Technol. 2011, 22, 21-39. [CrossRef]

126. Yamada, Y.; Iwasaki, M.; Usui, H.; Ohinata, K.; Marczak, E.D.; Lipkowski, A.W.; Yoshikawa, M. Rapakinin, an anti-hypertensive peptide derived from rapeseed protein, dilates mesenteric artery of spontaneously hypertensive rats via the prostaglandin IP receptor followed by CCK1 receptor. Peptides 2010, 31, 909-914. [CrossRef]

127. Zhang, S.B. In vitro antithrombotic activities of peanut protein hydrolysates. Food Chem. 2016, 202, 1-8. [CrossRef] [PubMed]

128. Kavitha, N.; Selvakumar, K.; Srinivasan, G.; Madhan, R. Production and analysis of microbial growth in enzyme hydrolysate of sesame oil seed cake. J. Biol. Inf. Sci. 2012, 1, 2-5.

129. Alashi, A.M.; Blanchard, C.L.; Mailer, R.J.; Agboola, S.O. Technological and Bioactive Functionalities of Canola Meal Proteins and Hydrolysates. Food Rev. Int. 2013, 29, 231-260. [CrossRef]

130. Campbell, L.; Rempel, C.; Wanasundara, J.P. Canola/Rapeseed Protein: Future Opportunities and Directions-Workshop Proceedings of IRC 2015. Plants 2016, 5, 17. [CrossRef] [PubMed]

131. Sisay, M.T.; Emire, S.A.; Ramaswamy, H.S.; Workneh, T.S. Effect of feed components on quality parameters of wheat-tef-sesame-tomato based extruded products. J. Food Sci. Technol. 2018, 55, 2649-2660. [CrossRef] [PubMed]

132. Stodolak, B.; Starzyńska-Janiszewska, A.; Wywrocka-Gurgul, A.; Wikiera, A. Solid-State Fermented Flaxseed Oil Cake of Improved Antioxidant Capacity as Potential Food Additive. J. Food Process. Preserv. 2016, 41, e12855. [CrossRef]

133. Sadh, P.K.; Chawla, P.; Duhan, J.S. Fermentation approach on phenolic, antioxidants and functional properties of peanut press cake. Food Biosci. 2018, 22, 113-120. [CrossRef]

134. Teh, S.-S.; Birch, E.J. Effect of ultrasonic treatment on the polyphenol content and antioxidant capacity of extract from defatted hemp, flax and canola seed cakes. Ultrason. Sonochemistry 2014, 21, 346-353. [CrossRef]

135. Bakkalbaşi, E. Oxidative stability of enriched walnut oil with phenolic extracts from walnut press-cake under accelerated oxidation conditions and the effect of ultrasound treatment. J. Food Meas. Charact. 2018, 13, 43-50. [CrossRef]

136. Şahin, S.; Elhussein, E.A.A. Assessment of sesame (Sesamum indicum L.) cake as a source of high-added value substances: From waste to health. Phytochem. Rev. 2018, 17, 691-700. [CrossRef]

137. Mohdaly, A.A.A.; Hassanien, M.F.R.; Mahmoud, A.; Sarhan, M.A.; Smetanska, I. Phenolics Extracted from Potato, Sugar Beet, and Sesame Processing By-Products. Int. J. Food Prop. 2013, 16, 1148-1168. [CrossRef]

138. Senanayake, C.M.; Algama, C.H.; Wimalasekara, R.L.; Weerakoon, W.N.; Jayathilaka, N.; Seneviratne, K.N. Improvement of Oxidative Stability and Microbial Shelf Life of Vanilla Cake by Coconut Oil Meal and Sesame Oil Meal Phenolic Extracts. J. Food Qual. 2019, 2019, 1-8. [CrossRef]

139. Teh, S.-S.; Bekhit, A.E.-D.; Birch, J. Antioxidative Polyphenols from Defatted Oilseed Cakes: Effect of Solvents. Antioxidants 2014, 3, 67-80. [CrossRef]

140. Pickardt, C.; Eisner, P.; Kammerer, D.R.; Carle, R. Pilot plant preparation of light-coloured protein isolates from de-oiled sunflower (Helianthus annuus L.) press cake by mild-acidic protein extraction and polyphenol adsorption. Food Hydrocoll. 2015, 44, 208-219. [CrossRef]

141. Sarkis, J.R.; Michel, I.; Tessaro, I.C.; Marczak, L.D.F. Optimization of phenolics extraction from sesame seed cake. Sep. Purif. Technol. 2014, 122, 506-514. [CrossRef]

142. Elleuch, M.; Bedigian, D.; Roiseux, O.; Besbes, S.; Blecker, C.; Attia, H. Dietary fibre and fibre-rich by-products of food processing: Characterisation, technological functionality and commercial applications: A review. Food Chem. 2011, 124, 411-421. [CrossRef]

143. Maphosa, Y.; Jideani, V.A. Dietary fiber extraction for human nutrition-A review. Food Rev. Int. 2015, 32, 98-115. [CrossRef]

144. Dhingra, D.; Michael, M.; Rajput, H.; Patil, R.T. Dietary fibre in foods: A review. J. Food Sci. Technol. 2011, 49, 255-266. [CrossRef]

145. Dungani, R.; Karina, M.; Sulaeman, A.; Hermawan, D.; Hadiyane, A. Agricultural Waste Fibers towards Sustainability and Advanced Utilization: A Review. Asian J. Plant Sci. 2016, 15, 42-55. [CrossRef]

146. Lizardi-Jiménez, M.A.; Hernández-Martínez, R. Solid state fermentation (SSF): Diversity of applications to valorize waste and biomass. 3 Biotech 2017, 7, 44. [CrossRef] 
147. Parihar, D.K. Production of Lipase Utilizing linseed oilcake as fermentation substrate. Int. J. Sci. Environ. Technol. 2012, 1, 135-143.

148. Thakur, S.A.; Nemade, S.N.; Sharanappa, A. Solid State Fermentation of Overheated Soybean Meal (Waste) For Production of Protease Using Aspergillus Oryzae. Int. J. Innov. Res. Sci. Eng. Technol. 2015, 4, 18456-18461. [CrossRef]

149. Gupta, A.; Sharma, A.; Pathak, R.; Kumar, A.; Sharma, S. Solid state fermentation of non-edible oil seed cakes for production of proteases and cellulases and degradation of anti-nutritional factors. J. Food Biotechnol. Res. 2018, 1, 3-8.

150. Sahoo, R.; Subudhi, E.; Kumar, M. Quantitative approach to track lipase producingPseudomonassp. S1 in nonsterilized solid state fermentation. Lett. Appl. Microbiol. 2014, 58, 610-616. [CrossRef]

151. Medhe, S.; Anand, M.; Anal, A.K. Dietary Fibers, Dietary Peptides and Dietary Essential Fatty Acids from Food Processing By-Products. In Food Processing By-Products and Their Utilization, 1st ed.; Anil, A.K., Ed.; John Wiley \& Sons Ltd.: Hoboken, NJ, USA, 2018; pp. 111-136.

152. Satya, C.V.; Anuradha, C.; Reddy, D.S. Palm Oil Cake: A Potential Substrate for L-Asparaginase production. Int. J. Innov. Res. Sci. Eng. Technol. 2014, 3, 14627-14632.

153. Ghosh, S.; Murthy, S.; Govindasamy, S.; Chandrasekaran, M. Optimization of L-asparaginase production by Serratia marcescens (NCIM 2919) under solid state fermentation using coconut oil cake. Sustain. Chem. Process. 2013, 1, 9. [CrossRef]

154. Gregori, A.; Pohleven, F. Cultivation of three medicinal mushroom species on olive oil press cakes containing substrates. Acta Agric. Slov. 2014, 103, 49-54. [CrossRef]

155. Song, B.; Ye, J.; Sossah, F.L.; Li, C.; Li, D.; Meng, L.; Xu, S.; Fu, Y.; Li, Y. Assessing the effects of different agro-residue as substrates on growth cycle and yield of Grifola frondosa and statistical optimization of substrate components using simplex-lattice design. AMB Express 2018, 8, 46. [CrossRef]

156. Krupodorova, T.A.; Barshteyn, V.Y. Alternative substrates for higher mushrooms mycelia cultivation. J. BioSci. Biotechnol. 2015, 1, 339-347.

157. Jape, A.; Salunke, D.; Dighe, S.; Harsulkar, A. The Improvement of Pleuorotus Species Cultivated On Soybean Straw Bed Supplemented with Flax Seed Meal. Int. J. Sci. Res. 2014, 3, 2012-2015.

158. Atila, F. Cultivation of Pleurotus spp., as an Alternative Solution to Dispose Olive Waste. J. Agric. Ecol. Res. Int. 2017, 12, 1-10. [CrossRef]

159. Zervakis, G.I.; Koutrotsios, G.; Katsaris, P. Composted versus Raw Olive Mill Waste as Substrates for the Production of Medicinal Mushrooms: An Assessment of Selected Cultivation and Quality Parameters. BioMed Res. Int. 2013, 2013, 1-13. [CrossRef] [PubMed]

160. Farzana, K.; Shah, S.N.H.; Butt, F.B.; Awan, S.B. Biosynthesis of bacitracin in solid-state fermentation by Bacillus licheniformis using defatted oil seed cakes as substrate. Pak. J. Pharm. Sci. 2005, 18, 55-57.

161. Zarei, I. Biosynthesis of Bacitracin in Stirred Fermenter by Bacillus Licheniformis Using Defatted Oil Seed Cakes as Substrate. Mod. Appl. Sci. 2012, 6, 30-36. [CrossRef]

162. Ali, S.; Nelofer, R.; Andleeb, S.; Baig, S.; Shakir, H.A.; Qazi, J.I. Biosynthesis and optimization of bacitracin by mutant Bacillus licheniformis using submerged fermentation. Indian J. Biotechnol. 2018, 17, 251-260.

163. Vastrad, B.M.; Neelagund, S.E. Optimization of Medium Composition for the Production of Neomycin byStreptomyces fradiaeNCIM 2418 in Solid State Fermentation. Biotechnol. Res. Int. 2014, 2014, 1-11. [CrossRef]

164. Nagavalli, M.; Ponamgi, S.P.; Girijashankar, V.; Venkateswar Rao, L. Solid State Fermentation and production of Rifamycin SV usingAmycolatopsis mediterranei. Lett. Appl. Microbiol. 2014, 60, 44-51. [CrossRef]

165. Vastrad, B.M.; Neelagund, S.E. Optimization of Process Parameters for Rifamycin B Production under Solid State Fermentation from Amycolatopsis Mediterranean Mtcc 14. Int. J. Curr. Pharm. Res. 2012, 4, 101-108.

166. Yao, D.; Ji, Z.; Wang, C.; Qi, G.; Zhang, L.; Ma, X.; Chen, S. Co-producing iturin A and poly- $\gamma$-glutamic acid from rapeseed meal under solid state fermentation by the newly isolated Bacillus subtilis strain 3-10. World J. Microbiol. Biotechnol. 2011, 28, 985-991. [CrossRef]

167. Banat, I.M.; Franzetti, A.; Gandolfi, I.; Bestetti, G.; Martinotti, M.G.; Fracchia, L.; Smyth, T.J.; Marchant, R. Microbial biosurfactants production, applications and future potential. Appl. Microbiol. Biotechnol. 2010, 87, 427-444. [CrossRef]

168. Thavasi, R. Microbial Biosurfactants: From an Environmental Application Point of View. J. Bioremediation Biodegrad. 2011, 2, 1000104. [CrossRef] 
169. Fracchia, L.; Cavallo, M.; Martinotti, G.M.; Banat, I.M. Biosurfactants and Bioemulsifiers Biomedical and Related Applications-Present Status and Future Potentials. In Biomedical Science, Engineering and Technology; Ghista, D.N., Ed.; InTecch Europe: Rijeka, Croatia, 2012; pp. 325-370.

170. Jiménez-Peñalver, P.; Koh, A.; Gross, R.; Gea, T.; Font, X. Biosurfactants from Waste: Structures and Interfacial Properties of Sophorolipids Produced from a Residual Oil Cake. J. Surfactants Deterg. 2019, 23, 481-486. [CrossRef]

171. Thavasi, R.; Nambaru, V.S.; Jayalakshmi, S.; Balasubramanian, T.; Banat, I.M. Biosurfactant Production by Pseudomonas aeruginosa from Renewable Resources. Indian J. Microbiol. 2011, 51, 30-36. [CrossRef]

172. Noparat, P.; Maneerat, S.; Saimmai, A. Utilization of palm oil decanter cake as a novel substrate for biosurfactant production from a new and promising strain of Ochrobactrum anthropi 2/3. World J. Microbiol. Biotechnol. 2014, 30, 865-877. [CrossRef] [PubMed]

173. Chittepu, O.R.; Reddy, C.O. Isolation and characterization of biosurfactant producing bacteria from groundnut oil cake dumping site for the control of foodborne pathogens. Grain Oil Sci. Technol. 2019, 2, 15-20. [CrossRef]

174. Zentek, J.; Knorr, F.; Mader, A. Reducing waste in fresh produce processing and households through use of waste as animal feed. In Global Safety of Fresh Produce: A Handbook of Best Practice, Innovative Commercial Solutions and Case Studies, 1st ed.; Hoorfar, J., Ed.; Woodhead Publishing Limited: Cambridge, UK, 2014; pp. 140-152.

175. Thu, T.N.; Bodin, N.; De Saeger, S.; Larondelle, Y.; Rollin, X. Substitution of fish meal by sesame oil cake (Sesamum indicum L.) in the diet of rainbow trout (Oncorhynchus mykiss W.). Aquac. Nutr. 2010, 17, 80-89. [CrossRef]

176. Chebaibi, S.; Grandchamp, M.L.; Burgé, G.; Clément, T.; Allais, F.; Laziri, F. Improvement of protein content and decrease of anti-nutritional factors in olive cake by solid-state fermentation: A way to valorize this industrial by-product in animal feed. J. Biosci. Bioeng. 2019, 128, 384-390. [CrossRef]

177. Hassan, H.E.; Elhashmi, Y.H.A.; Eldar, A.A.T.; Elamin, K.M.; Elbushra, M.E. Effects of Feeding Different Levels of Sesame Oil Cake (Sesamum indicum L.) On Performance and Carcass Characteristics of Sudan Desert Sheep. J. Anim. Sci. Adv. 2013, 3, 91. [CrossRef]

178. Fitwi, M.; Tadesse, G. Effect of sesame cake supplementation on feed intake, body weight gain, feed conversion efficiency and carcass parameters in the ration of sheep fed on wheat bran and teff (Eragrostis teff) straw. Momona Ethiop. J. Sci. 2013, 5, 89. [CrossRef]

179. Ghorbani, B.; Yansari, A.T.; Sayyadi, A.J. Effects of sesame meal on intake, digestibility, rumen characteristics, chewing activity and growth of lambs. S. Afr. J. Anim. Sci. 2018, 48, 151. [CrossRef]

180. Mir, M.A.; Sharma, R.K.; Rastogi, A.; Haq, Z.; Ganai, I.A. Effect of dietary incorporation of walnut cake (Juglans regia) on calcium-Phosphorus balance and blood biochemical parameters in goats. Vet. Arhiv 2018, 88, 763-771. [CrossRef]

181. Chipa, M.J.; Siebrits, F.K.; Ratsaka, M.M.; Leeuw, K.J.; Nkosi, B.D. Growth performance of feedlot weaners cattle fed diet containing different levels of cold press soya bean oilcake. S. Afr. J. Anim. Sci. 2010, 40, 499-501.

182. Stübler, A.-S.; Heinz, V.; Aganovic, K. Development of food products. Curr. Opin. Green Sustain. Chem. 2020, 25, 100356. [CrossRef]

183. Sunil, L.; Prakruthi, A.; Prasanth Kumar, P.K.; Gopala Krishna, A.G. Development of Health Foods from Oilseed Cakes. J. Food Process. Technol. 2016, 7, 1-6. [CrossRef]

184. Pycia, K.; Kapusta, I.; Jaworska, G. Walnut oil and oilcake affect selected the physicochemical and antioxidant properties of wheat bread enriched with them. J. Food Process. Preserv. 2020, 44, e14573. [CrossRef]

185. Koneva, S.I.; Egorova, E.Y.; Kozubaeva, L.A.; Kuzmina, S.S.; Zakharova, A.S. Influence of Flaxseed Flour on Dough Rheology from Wheat-Flaxseed Meal. In International Scientific and Practical Conference "AgroSMART—Smart Solutions for Agriculture" (AgroSMART 2018); Atlantis Press: Paris, France, 2018; pp. 370-377.

186. Behera, S.; Indumathi, K.; Mahadevamma, S.; Sudha, M.L. Oil cakes-A by-product of agriculture industry as a fortificant in bakery products. Int. J. Food Sci. Nutr. 2013, 64, 806-814. [CrossRef]

187. Jáquez, D.R.; Casillas, F.; Flores, N.; Cooke, P.; Licon, E.D.; Soto, S.; González, I.A.; Carreón, F.O.C.; Roldán, H.M. Effect of Glandless Cottonseed Meal Content on the Microstructure of Extruded Corn-Based Snacks. Adv. Food Sci. 2014, 36, 125-130.

188. Bulut, S.; Lazić, V.; Mađarev-Popović, S.; Hromiš, N.; Šuput, D. Mono- and bilayer biopolymer films: Synthesis and characterisation. J. Process. Energy Agric. 2017, 21, 214-218. [CrossRef]

189. Garrido, T.; Leceta, I.; Cabezudo, S.; Guerrero, P.; De La Caba, K. Tailoring soy protein film properties by selecting casting or compression as processing methods. Eur. Polym. J. 2016, 85, 499-507. [CrossRef] 
190. Garrido, T.; Etxabide, A.; Peñalba, M.; De La Caba, K.; Guerrero, P. Preparation and characterization of soy protein thin films: Processing-properties correlation. Mater. Lett. 2013, 105, 110-112. [CrossRef]

191. Puscaselu, R.G.; Gutt, G.; Amariei, S. Rethinking the Future of Food Packaging: Biobased Edible Films for Powdered Food and Drinks. Molecules 2019, 24, 3136. [CrossRef] [PubMed]

192. Popović, S.; Hromiš, N.; Šuput, D.; Bulut, S.; Romanić, R.; Lazić, V. Valorization of by-products from the production of pressed edible oils to produce biopolymer films. In Cold Pressed Oils, 1st ed.; Ramadan, F.M., Ed.; Elsevier Inc.: London, UK, 2020; pp. 15-30.

193. Šuput, D.; Mađarev-Popović, S.; Hromiš, N.; Bulut, S.; Lazić, V. Biopolymer films properties change affected by essential oils addition. J. Process. Energy Agric. 2019, 23, 61-65. [CrossRef]

194. Salgado, P.R.; Ortiz, S.E.M.; Petruccelli, S.; Mauri, A.N. Biodegradable sunflower protein films naturally activated with antioxidant compounds. Food Hydrocoll. 2010, 24, 525-533. [CrossRef]

195. Mađarev-Popović, S.; Lazic, V.; Popovic, L.; Vaštag, Ž.; Pericin, D. Effect of the addition of pumpkin oil cake to gelatin to produce biodegradable composite films. Int. J. Food Sci. Technol. 2010, 45, 1184-1190. [CrossRef]

196. Mađarev-Popović, S.; Pericin, D.; Vaštag, Ž.; Popovic, L.; Lazic, V. Evaluation of edible film-forming ability of pumpkin oil cake; effect of $\mathrm{pH}$ and temperature. Food Hydrocoll. 2011, 25, 470-476. [CrossRef]

197. Bulut, S.; Lazic, V.; Popovic, S.; Hromiš, N.; Šuput, D. Influence of storage period on properties of biopolymer packaging materials and pouches. Acta Period. Technol. 2017, 48, 53-62. [CrossRef]

198. Bulut, S.; Lazic, V.; Popovic, S.; Hromis, N.; Suput, D. Influence of different concentrations of glycerol and guar xanthan on properties of pumpkin oil cake-zein bi-layer film. Ratar. Povrt. 2017, 54, 19-24. [CrossRef]

199. Bulut, S.; Mađarev-Popović, S.; Hromiš, N.; Šuput, D.; Lazić, V.; Malbaša, R.; Vitas, J.S. Incorporation of essential oils into biopolymer films based on pumpkin oil cake in order to improve their antioxidant activity. J. Process. Energy Agric. 2019, 23, 162-166. [CrossRef]

200. Mađarev-Popović, S.; Peričin, D.; Vaštag, Ž.; Lazić, V.; Popović, L.M. Pumpkin oil cake protein isolate films as potential gas barrier coating. J. Food Eng. 2012, 110, 374-379. [CrossRef]

201. Reddy, N.; Jiang, Q.; Yang, Y. Preparation and properties of peanut protein films crosslinked with citric acid. Ind. Crop. Prod. 2012, 39, 26-30. [CrossRef]

202. Sun, Q.; Sun, C.; Xiong, L. Mechanical, barrier and morphological properties of pea starch and peanut protein isolate blend films. Carbohydr. Polym. 2013, 98, 630-637. [CrossRef]

203. Riveros, C.G.; Martin, M.P.; Aguirre, A.; Grosso, N.R. Film preparation with high protein defatted peanut flour: Characterisation and potential use as food packaging. Int. J. Food Sci. Technol. 2017, 53, 969-975. [CrossRef]

204. Wan, J.; Liu, C.; Liu, W.; Tu, Z.; Wu, W.; Tan, H. Optimization of instant edible films based on dietary fiber processed with dynamic high pressure microfluidization for barrier properties and water solubility. LWT 2015, 60, 603-608. [CrossRef]

205. Ghodrat, A.G.; Tabatabaei, M.; Aghbashlo, M.; Mussatto, S.I. Waste Management Strategies the State of the Art. In Biogas Fundamentals, Process and Operation; Tabatabaei, M., Ghanavati, H., Eds.; Springer International Publishing: Cham, Switzerland, 2018; Volume 6, pp. 1-33.

206. Cheng, F.; Bayat, H.; Jena, U.; Brewer, C.E. Impact of feedstock composition on pyrolysis of low-cost, protein- and lignin-rich biomass: A review. J. Anal. Appl. Pyrolysis 2020, 147, 104780. [CrossRef]

Publisher's Note: MDPI stays neutral with regard to jurisdictional claims in published maps and institutional affiliations.

(C) 2020 by the authors. Licensee MDPI, Basel, Switzerland. This article is an open access article distributed under the terms and conditions of the Creative Commons Attribution (CC BY) license (http://creativecommons.org/licenses/by/4.0/). 